\title{
Regional diving behavior of Pacific Arctic beluga whales Delphinapterus leucas and possible associations with prey
}

\author{
Donna D. W. Hauser ${ }^{1, *}$, Kristin L. Laidre ${ }^{1,2}$, Sandra L. Parker-Stetter ${ }^{1,3}$, \\ John K. Horne ${ }^{1}$, Robert S. Suydam ${ }^{4}$, Pierre R. Richard ${ }^{5}$ \\ ${ }^{1}$ University of Washington, School of Aquatic \& Fishery Sciences, Box 355020, Seattle, WA 98195, USA \\ ${ }^{2}$ University of Washington, Polar Science Center, Applied Physics Laboratory, 1013 NE $40^{\text {th }}$ Street, Seattle, WA 98195, USA \\ ${ }^{3}$ Fisheries Resource Assessment and Monitoring Division, Northwest Fisheries Science Center, \\ National Marine Fisheries Service, National Oceanic and Atmospheric Administration, 2725 Montlake Boulevard East, \\ Seattle, WA 98112, USA \\ ${ }^{4}$ North Slope Borough, Department of Wildlife Management, PO Box 69, Barrow, AK 99723, USA \\ ${ }^{5}$ Freshwater Institute, Fisheries and Oceans Canada, 501 University Crescent, Winnipeg, MB R3T 2N6, Canada
}

\begin{abstract}
Two populations of beluga whales Delphinapterus leucas in the Pacific Arctic make seasonal migrations to regions characterized by diverse bathymetry and hydrography, yet there is limited information contrasting behavior and foraging across regions. We used satellite-linked time-depth recorders attached to 30 belugas from 1997 to 2012 to infer the depths at which belugas forage seasonally and regionally. We also examined the correspondence between patterns of beluga diving and the vertical distribution of a primary prey species, Arctic cod Boreogadus saida, within the western Beaufort Sea. A suite of regional diving metrics revealed that beluga dive behavior varied among regions and sometimes between populations. Estimates of occupancy time at depth, in addition to maximum and modal dive depths for $6 \mathrm{~h}$ periods, suggested that Eastern Chukchi Sea and Beaufort Sea belugas were regularly diving to the seafloor in shallow shelf regions. Along slope margins and in the deep Canada Basin $(>3000 \mathrm{~m})$, specific portions of the water column were more frequently targeted. The greatest maximum daily dive depths were $>900 \mathrm{~m}$ in the Canada Basin. Arctic cod were most abundant at $200-300 \mathrm{~m}$ in the western Beaufort Sea, and beluga dives within the survey area also most frequently targeted these depths. These results are consistent with a hypothesis that Arctic cod are a primary prey item for Pacific Arctic belugas and suggest that foraging belugas dive to depths that maximize prey encounters. In the context of a rapidly transforming Arctic ecosystem increasingly exposed to anthropogenic activities, our results quantify the ecological importance of key regions for these 2 populations.
\end{abstract}

KEY WORDS: Diving behavior - Arctic marine ecology · Foraging ecology · Optimal foraging • Chukchi Sea $\cdot$ Beaufort Sea $\cdot$ Boreogadus saida

Resale or republication not permitted without written consent of the publisher

\section{INTRODUCTION}

Optimal foraging theory predicts that predators aim to maximize energy intake through prey consumption while simultaneously minimizing the time and energy required to obtain that prey (Schoener
1971). For air-breathing marine predators, an additional constraint is imposed by oxygen demands limiting foraging time. Accordingly, predators minimize their transit time to optimize foraging before surfacing and recovering from oxygen depletion (Boyd 1997). In addition to physiological limits, other factors 
such as quality and distribution of prey affect dive duration (Thompson \& Fedak 2001, Thums et al. 2013). Animals that frequently dive deep trade off foraging needs over the physiological demands of diving deeply (Davis 2014). As a result, depth layers of the water column where divers frequently visit or spend extended periods of time can indicate where foraging is focused (Laidre et al. 2003, Robinson et al. 2012).

Marine environments also present a complex suite of factors that may influence the dive behavior of marine predators. Dive depths can vary according to prey density at depth, as well as the habitat characteristics (e.g. bathymetry, hydrography, presence of sea ice) encountered. Indices of dive depth relative to ocean depth can indicate pelagic or benthic foraging (Jessopp et al. 2013, Watt et al. 2015), and maximum dive depth may identify specific foraging depths (Photopoulou et al. 2014). Understanding patterns of prey within the water column provides additional context for interpreting diving behavior where estimates of prey distribution, abundance, or density can inform a mechanistic understanding of marine mammal diving, foraging at depth, and habitat use (e.g. Palacios et al. 2013, Witteveen et al. 2015).

Beluga whales Delphinapterus leucas are generalist predators, occurring in a number of habitat types and feeding on diverse prey (Laidre et al. 2008). In the Pacific Arctic, some belugas migrate thousands of kilometers seasonally as the annual sea ice recedes and advances (Richard et al. 2001, Suydam et al. 2001, Suydam 2009). Two beluga populations, the Beaufort Sea (BS) and Eastern Chukchi Sea (ECS), winter in the northern Bering Sea before migrating during spring into the Beaufort and Chukchi Seas (Frost \& Lowry 1990) as well as the deep (>3000 m) Canada Basin where they are generally spatially and temporally segregated during summer to fall (Hauser et al. 2014). Managed as separate stocks with distinct mitochondrial DNA signatures ( $\mathrm{O}^{\prime}$ Corry-Crowe et al. 1997, Allen \& Angliss 2014), spatial overlap between populations is greatest in fall, when BS belugas initiate westward migration to the Chukchi Sea ahead of the ECS westward migration (Hauser et al. 2014). Both populations commence southward passage through the Bering Strait in November. These belugas use different habitats over the range of their seasonal migrations, and each region is characterized by complex hydrography, diverse topography, seasonal sea ice fluctuations, and freshwater input that presumably influence prey distributions and foraging arenas for diving belugas (Weingartner et al. 1998, Day et al. 2013).
The limited information on BS beluga diving behavior suggests that most dives are 'square-shaped' to the seafloor in Beaufort Sea waters 15 to $600 \mathrm{~m}$ deep, or 'V-shaped' to 700-900 $\mathrm{m}$ in deep (>600 m) areas over the Canada Basin (Richard et al. 1997). Recent analyses of ECS beluga diving suggest that regional differences exist in the proportion of time spent at depth, modal depths, and dive durations (Citta et al. 2013). Looking across inshore shelf $(<75 \mathrm{~m})$, slope $(75-400 \mathrm{~m})$, basin $(>400 \mathrm{~m})$, and Barrow Canyon regions, Citta et al. (2013) found that ECS shallow-type diving $(<50 \mathrm{~m})$ most often occurred in shelf waters compared to deep diving (with 1 mode at $<50 \mathrm{~m}$ and another at $>400 \mathrm{~m}$ ) in the Canada Basin. However, intermediate diving (with 1 mode at $<50 \mathrm{~m}$ and another near $250 \mathrm{~m}$ ) was found in all but the shelf regions. ECS beluga diving in slope areas and the Barrow Canyon tended to coincide with depths where regional hydrographic conditions are commonly assumed to concentrate prey such as Arctic cod Boreogadus saida. Available stomach content and fatty acid diet information suggest that adult Arctic cod are a primary prey item of both BS and ECS belugas, although other fish (e.g. saffron cod Eleginus gracilis), cephalopods (primarily octopus), and benthic invertebrates (primarily crangonid shrimp or echiurid worms) have been recorded (Seaman et al. 1982, Loseto et al. 2009, Quakenbush et al. 2015). Arctic cod make up the bulk of surveyed fish biomass in the Pacific Arctic, yet have only been surveyed in the nearshore shelf, and more recently, slope waters of the Chukchi and Beaufort Seas (Parker-Stetter et al. 2011, Norcross et al. 2013, Logerwell et al. 2015).

Both BS and ECS populations are considered to be stable (Allen \& Angliss 2014), although recent evidence suggests a decline in BS growth rates (Harwood et al. 2014). This decline is coincident with downward trends in body condition or reproduction of other Beaufort Sea marine predators that also primarily consume Arctic cod (Harwood et al. 2015). Harwood et al. $(2014,2015)$ suggested that these shifts in life history parameters are related to recent Pacific Arctic ecosystem changes (e.g. Grebmeier 2012) affecting prey, further indicating the importance of understanding foraging behavior and beluga relationships with prey.

Little work has been done to investigate interpopulation differences in dive behavior for BS and ECS belugas, or to quantify how diving is related to foraging at depth. We used diving information from 30 beluga whales tagged with satellite transmitters linked to time-depth recorders to quantify differ- 
ences in underwater behavior between populations and among regions. Our goal was to identify the depths and portions of the water column targeted by belugas within diverse oceanographic and bathymetric regions of the Pacific Arctic. We inferred foraging behavior for BS and ECS belugas based on the depths where belugas exhibited prolonged time at depth after accounting for the time spent traveling to and from each depth as well as modal and maximum dive depths. We then estimated whether diving was in close proximity to the seafloor or pelagic portions of the water column to indicate potential demersal or water-column foraging. Additionally, we examined patterns of ECS beluga diving relative to the vertical distribution of a primary prey item, Arctic cod, in the western Beaufort Sea. We compared a subset of ECS beluga diving data to the vertically integrated densities of Arctic cod from a fisheries acoustic survey (Parker-Stetter et al. 2011) and hypothesized that the number of beluga dives to target depths is positively related to the density of Arctic cod at the same depths. Although limited in spatial and temporal resolution, this analysis allowed us to explore the relationship between beluga diving behavior and prey abundance as well as to evaluate the use of our diving parameters as indicators of foraging behavior.

\section{MATERIALS AND METHODS}

\section{Study area and region definition}

The regions of the Pacific Arctic are characterized by complex hydrography and diverse bathymetry affecting habitat and ecosystem structure (Carmack \& Wassman 2006; Fig. 1). The northern Bering Sea is comprised of the shallow Chirikov Basin $(<75 \mathrm{~m})$ and is connected to the Chukchi Sea via the narrow $(\sim 80 \mathrm{~km}$ wide) Bering Strait. The Chukchi Sea has complex, but shallow (<75 m everywhere but the northern perimeter), bathymetry characterized by several canyons and distinct water masses that can be strongly affected by wind-driven circulation (Danielson et al. 2014). The Alaska Coastal Current (ACC) flows from the northeast Chukchi Sea into the narrow, steeply sloped Alaska Beaufort Sea through Barrow Canyon (Pickart 2004), where wind forcing affects the presence of belugas and presumed foraging opportunities (Stafford et al. 2013). The warm, fresh ACC joins a shelfbreak jet along the Beaufort Sea slope, sometimes reaching the Canada Beaufort Sea (von Appen \& Pickart 2012). Eddies spin off the shelfbreak jet into the deep, offshore Canada Basin

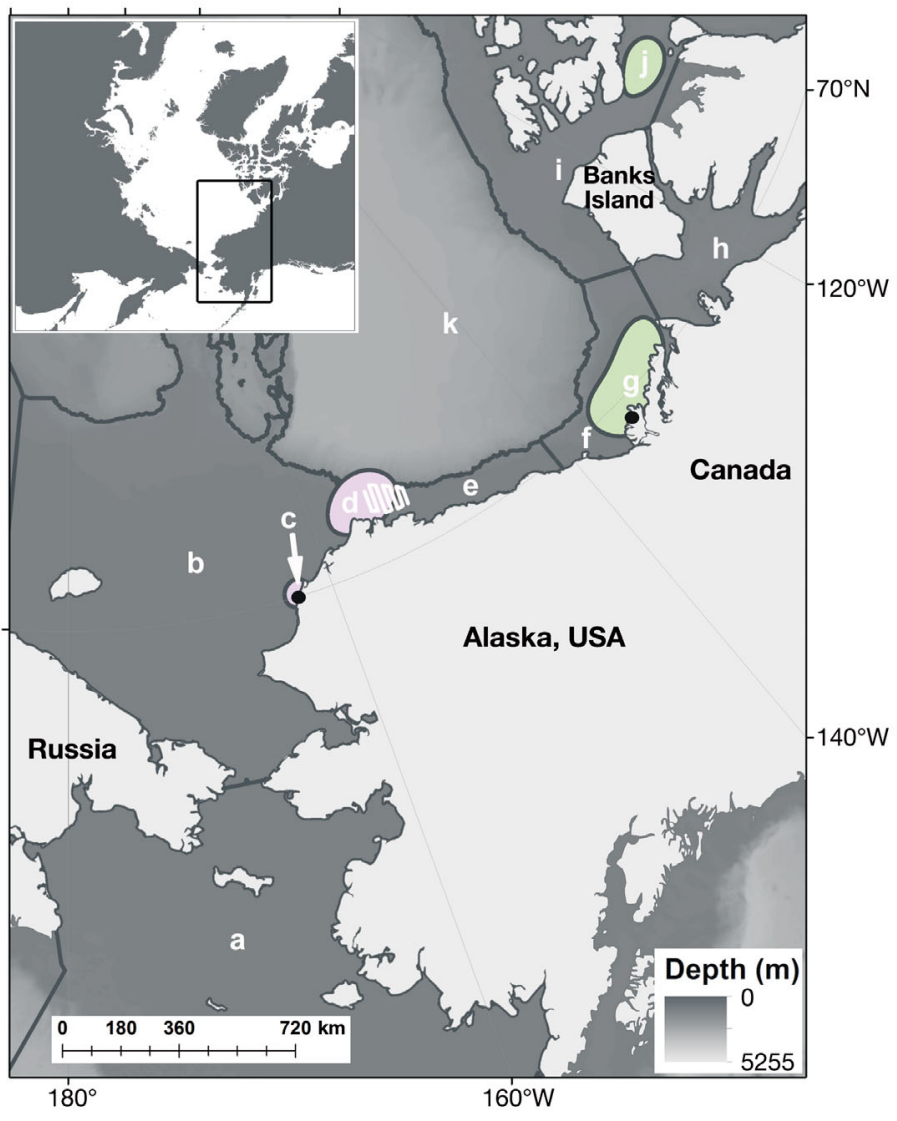

Fig. 1. Eleven regions (and habitat types) of the Pacific Arctic used to examine regional diving behavior of Beaufort Sea (BS) and Eastern Chukchi Sea (ECS) beluga whales Delphinapterus leucas: a, northern Bering Sea (shallow shelf); b, Chukchi Sea (shallow shelf); c, Kasegaluk Lagoon ECS summer core area (shallow shelf); d, Barrow Canyon ECS summer core area (slope); e, Alaska Beaufort Sea (slope); f, Canada Beaufort Sea (slope); g, Mackenzie Estuary BS summer core area (shallow shelf); h, Amundsen Gulf (slope); i, east slope of Canada Basin (slope); j, Viscount Melville Sound BS summer core area (slope); and k, Canada Basin (pelagic deep). Summer core areas follow Hauser et al. (2014); green and purple areas correspond to BS and ECS core areas, respectively. Black circles indicate approximate tagging locations, including Point Lay, Alaska, USA (ECS population, west circle) and the Mackenzie River Estuary, Canada (BS population, east circle). The location of a 2008 survey for Arctic cod (ParkerStetter et al. 2011) is shown as the white trackline

(Spall et al. 2008), and upwelling along the slope is common (Pickart et al. 2013). Outflow from the Mackenzie River joins the shelfbreak jet and typically flows eastward over the shallow and wide Canada Beaufort sea shelf, forming a turbid plume over the Mackenzie Estuary (Carmack \& Macdonald 2002). The plume continues into the steep-sloped Amundsen Gulf where wind-forced upwelling occurs near Cape Bathurst and a thermohalocline forms in mid-water depths. 
We collected movement and diving behavior from BS and ECS belugas throughout the Pacific Arctic. To assess diving by belugas across the range of habitats in the Pacific Arctic, we designated 11 regions based on variable habitat types in the Pacific Arctic, previous descriptions of BS and ECS beluga distribution (Richard et al. 2001, Suydam et al. 2001, Suydam 2009), summer core areas (Hauser et al. 2014), and the $400 \mathrm{~m}$ isobath (Fig. 1). The $400 \mathrm{~m}$ isobath has been used in previous assessments of beluga diving (Citta et al. 2013) and was the maximum depth sampled by beluga tags in some years (Table S1 in the Supplement, available at www.int-res.com/articles/suppl/ m541p245_supp.pdf). Bathymetry and hydrography affects habitat type (i.e. 'shallow shelf,' 'slope,' and 'deep pelagic') for each region, and belugas use each region at different times during seasonal migrations (Table 1).

\section{Beluga whale telemetry data}

Belugas were captured and tagged near the Mackenzie River Estuary (BS in 1997 and 2005) and Point Lay, Alaska, USA (ECS in 1998, 1999, 2001, 2002, 2007, 2010, and 2012) in association with local subsistence harvests (cf. Orr et al. 2001, Richard et al. 2001, Suydam et al. 2001, Hauser et al. 2014). All tags were

Table 1. Study regions (see Fig. 1) and number of tagged Eastern Chukchi Sea (ECS; total $n=26)$ and Beaufort Sea (BS; total $n$ = 4) beluga whales Delphinapterus leucas in each region, including the number of $6 \mathrm{~h}$ maximum-depth periods. Habitat types vary according to bathymetry and hydrography. Median depth (range in parentheses) measured by the location of $6 \mathrm{~h}$ dive periods are also shown for each region. Minimum depths of $0 \mathrm{~m}$ correspond to locations very close to shore, based on a mean high water vertical datum (Jakobsson et al. 2012). The first to last day of the year and season (summer = July-August, fall = September-October, winter $=$ November-April, spring $=$ May-June) when a tagged whale was located in each region are indicated; -: no tagged whales occurred in the region

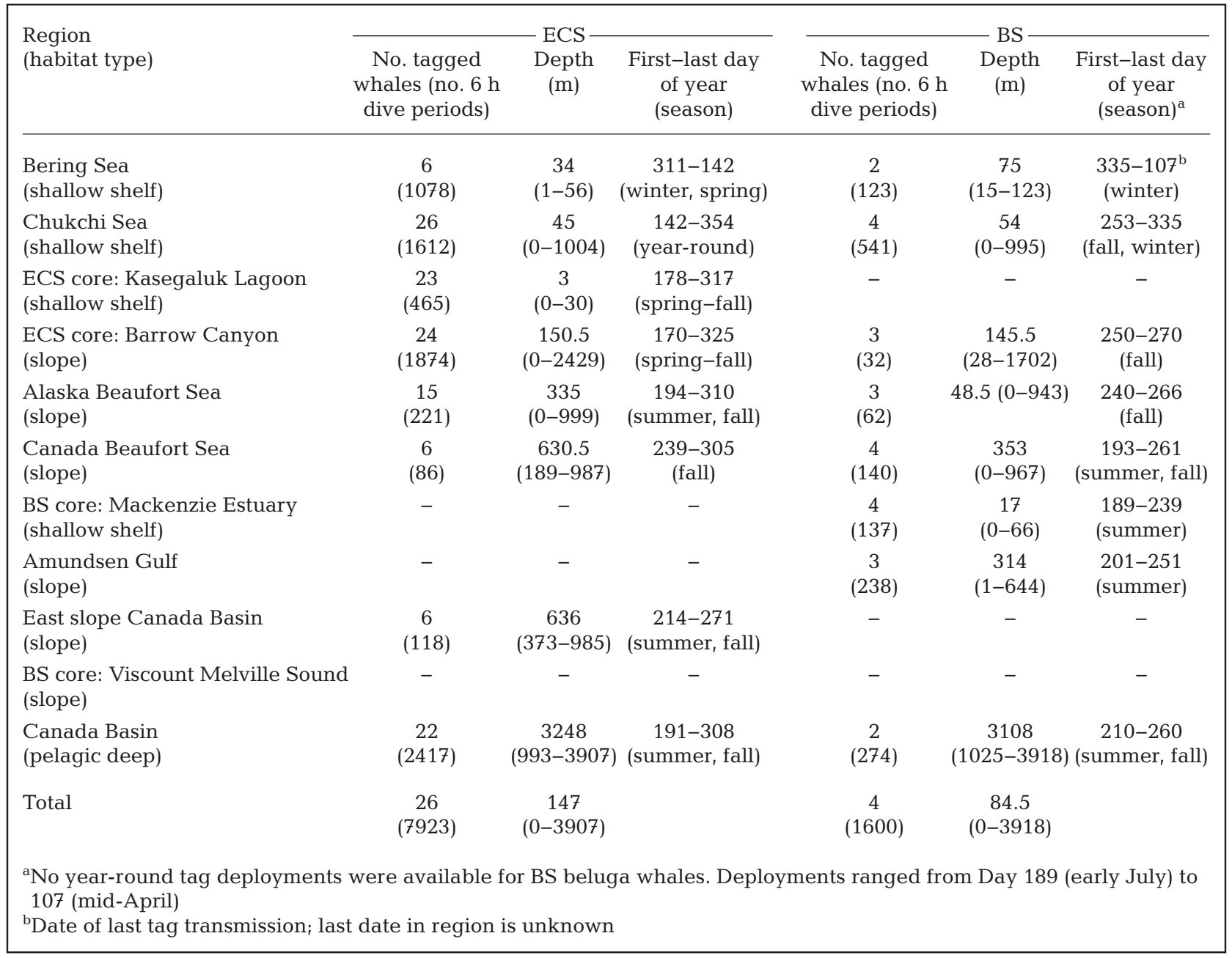


manufactured by Wildlife Computers and consisted of ST-10, ST-16, SPLASH, and MK10 transmitters. Most tags were deployed in early July, with tag duration varying by individual (Table 2). All tags transmitted continuously except 2 BS tags in 2005, which were programmed to transmit every $4 \mathrm{~d}$ to conserve battery life.

We obtained location data, associated error classes, and binned dive histograms from the Argos data system. The first $24 \mathrm{~h}$ of location and dive data post-tag deployment were excluded to eliminate any potential behavioral effects resulting from capture and tagging. Speed (maximum $6.4 \mathrm{~km} \mathrm{~h}^{-1}$, Richard et al.

Table 2. Beluga whales Delphinapterus leucas tagged in the Beaufort Sea $(B S, n=4)$ and Eastern Chukchi Sea $(E C S, n=26)$ populations near the Mackenzie River Estuary, Canada, and Point Lay, AK, USA, respectively. Adult (ADU) or immature (IMM) reproductive status was visually assessed based on size, coloration, and presence of a calf if possible. Tag duration refers to the number of days dive data were collected and used in the present study

\begin{tabular}{|c|c|c|c|c|c|c|}
\hline Year & Tag ID & Sex & $\begin{array}{l}\text { Length } \\
\text { (cm) }\end{array}$ & $\begin{array}{c}\text { Reproductive } \\
\text { status }\end{array}$ & $\begin{array}{l}\text { Capture } \\
\text { date }\end{array}$ & $\begin{array}{c}\text { Tag } \\
\text { duration (d) }\end{array}$ \\
\hline \multicolumn{7}{|l|}{ BS } \\
\hline \multirow[t]{2}{*}{1997} & $97-2118$ & F & 374 & $\mathrm{ADU}$ & 26 July & 127 \\
\hline & $97-25846$ & M & 374 & IMM & 29 July & 83 \\
\hline \multirow[t]{2}{*}{2005} & 05-57591 & F & 275 & IMM & 5 July & 283 \\
\hline & 05-57593 & $\mathrm{F}$ & 350 & $\mathrm{ADU}$ & 10 July & 157 \\
\hline \multicolumn{7}{|l|}{ ECS } \\
\hline \multirow[t]{5}{*}{1998} & 98-11035 & M & 440 & $\mathrm{ADU}$ & 26 June & 11 \\
\hline & $98-2284$ & M & 432 & $\mathrm{ADU}$ & 28 June & 13 \\
\hline & $98-11036$ & M & 398 & ADU & 29 June & 98 \\
\hline & $98-2285$ & M & 415 & ADU & 29 June & 89 \\
\hline & $98-2282$ & M & 414 & $\mathrm{ADU}$ & 1 July & 58 \\
\hline \multirow[t]{4}{*}{1999} & 99-11035 & M & 418 & $\mathrm{ADU}$ & 30 June & 85 \\
\hline & 99-11036 & $\mathrm{F}$ & 266 & IMM & 30 June & 73 \\
\hline & $99-11037$ & M & 424 & $\mathrm{ADU}$ & 30 June & 55 \\
\hline & $99-11041$ & M & 424 & $\mathrm{ADU}$ & 30 June & 84 \\
\hline \multirow[t]{8}{*}{2001} & 01-2093 & M & 381 & ADU & 3 July & 36 \\
\hline & 01-2094 & $\mathrm{F}$ & 359 & $\mathrm{ADU}$ & 3 July & 17 \\
\hline & $01-11038$ & $\mathrm{~F}$ & 316 & IMM & $5-\mathrm{Jul}$ & 145 \\
\hline & 01-11041 & M & 324 & IMM & 5 July & 145 \\
\hline & $01-2280$ & $\mathrm{~F}$ & 335 & IMM & 5 July & 107 \\
\hline & 01-11037 & M & 340 & $\mathrm{ADU}$ & 7 July & 131 \\
\hline & $01-228$ & M & 320 & IMM & 7 July & 15 \\
\hline & 01-2282 & M & 373 & $\mathrm{ADU}$ & 7 July & 35 \\
\hline \multirow[t]{3}{*}{2002} & $02-11036$ & F & 320 & IMM & 7 July & 66 \\
\hline & $02-11044$ & M & 276 & IMM & 7 July & 80 \\
\hline & $02-2088$ & M & 267 & IMM & 8 July & 62 \\
\hline \multirow[t]{3}{*}{2007} & $07-77015$ & F & 386 & $\mathrm{ADU}$ & 1 July & 132 \\
\hline & $07-36516$ & $\mathrm{~F}$ & 398 & $\mathrm{ADU}$ & 1 July & 125 \\
\hline & $07-22149$ & M & 430 & $\mathrm{ADU}$ & 1 July & 520 \\
\hline \multirow[t]{2}{*}{2010} & $10-22117$ & M & 305 & IMM & 30 June & 157 \\
\hline & $10-36517$ & M & 345 & $\mathrm{ADU}$ & 30 June & 99 \\
\hline 2012 & $12-108772$ & $\mathrm{~F}$ & 328 & $\mathrm{ADU}$ & 9 July & 303 \\
\hline
\end{tabular}

2001) and angle filters were used to eliminate unlikely locations (Freitas et al. 2008). The tags contained pressure transducers which sampled whale depths at a resolution of 0.5 (2005-2012 tags), 2 (1997 tags), or 4 m (1998-2002 tags). Satellite data transmission limitations required diving data to be compressed into four $6 \mathrm{~h}$ histograms per day. Dive data comprised 3 types of histograms: the number of dives to maximum depth layers ('maximum depth' histogram periods), the proportional time within each depth layer ('time-at-depth' histogram periods), and number of dives to dive duration categories ('duration' histogram periods). We pre-specified depth layers (or 'bins') for each histogram type before deployment, but different bin thresholds were used among histogram types, populations, and tagging years (see Table S1) as tag technology improved and for different research purposes (e.g. see Richard et al. 1997, Citta et al. 2013). For analysis, we consolidated bins to the finest resolution available among all years and populations: $0-10,10-50,50-100,100-$ 200, 200-300, 300-400, >400 m for maximum-depth $6 \mathrm{~h}$ periods; 0-10, 10-50, 50$100,100-200,200-400$, >400 $\mathrm{m}$ for timeat-depth $6 \mathrm{~h}$ periods; and $0-1,1-3,3-6,6-$ 9, 9-20, > $20 \mathrm{~min}$ for duration $6 \mathrm{~h}$ periods. We sampled time-at-depth layers differently than maximum-depth layers in 1 year (2005), so slightly coarser time-atdepth layers were necessary when consolidated for analysis (Table S1). A depth of at least 2 or $4 \mathrm{~m}$ (for 2007-2012 tags and 1997-2005 tags, respectively) was required before a dive was registered on the tag. We used a correlated random walk model to estimate geographic locations at the beginning of each $6 \mathrm{~h}$ period based on observed locations and associated Argos spatial error (Johnson et al. 2008). Six ECS tags from 2007, 2010, and 2012 also provided maximum daily dive depth (to a maximum of $1000 \mathrm{~m}$ ), recorded as the maximum absolute depth measured by the tag within the previous $24 \mathrm{~h}$. Thus, maximum daily dive depths were point estimates for a $24 \mathrm{~h}$ period measured with higher resolution than the dive data summarized in $6 \mathrm{~h}$ maximum-depth periods. We assigned the daily location from Hauser et al. (2014) to each maximum daily dive depth. 


\section{Mapping beluga whale dive behavior}

Beluga dive characteristics, including deepest ('maximum') and modal depth and longest dive duration, were identified for each $6 \mathrm{~h}$ period and mapped using ArcGIS 10.1 (ESRI). Prey searching and capture may occur throughout the water column, but we examined the deepest and modal depths in each $6 \mathrm{~h}$ period as indicators of where diving was focused as presumed foraging effort, both extracted from the maximum-depth histograms. Maximum dive depth has been used as a proxy for specific foraging depth in other marine mammals (e.g. Photopoulou et al. 2014), and we also examined modal depths to consider which depths were most frequently used. We assumed the longest dive durations, extracted from the duration histograms for each $6 \mathrm{~h}$ period, were associated with deeper dives indicative of foraging effort (e.g. Davis et al. 2013). However, dive depth and duration were not directly linked, and we cannot verify that longer dives were also deeper dives (Citta et al. 2013).

The maximum daily dive depths from the 20072012 ECS whales were also mapped to describe deep diving at a higher resolution than previously available or possible from the histogram data. We presumed that maximum daily depth also provided an indicator of the deepest depths at which foraging may occur. We compared maximum daily dive depth among regions using linear mixed effects (LME) models fit with maximum likelihood methods in the 'nlme' package (Pinheiro et al. 2013) in R (R Development Core Team 2012). Individual whales were treated as a random effect to account for repeated measures, and regions were considered a fixed effect. We excluded the Canada Basin eastern slope region from the LME due to small sample size.

The depth associated with each $6 \mathrm{~h}$ period's location was extracted from the $500 \mathrm{~m}$ resolution International Bathymetric Chart for the Arctic Ocean (IBCAO; Jakobsson et al. 2012). Some dive locations ( $\mathrm{n}=74,1 \%$ ) occurred south of the IBCAO extent in the northern Bering Sea, where we used the 1 arcminute ETOPO1 global relief map (Amante \& Eakins 2009). We also recorded whether the deepest and modal depths in a $6 \mathrm{~h}$ period overlapped with the depth of the seafloor (categorical yes/no), the proximity to the seafloor as a ratio of the modal depth in a $6 \mathrm{~h}$ period relative to seafloor depth (range 0-1), as well as the ratio of maximum daily dive depth to seafloor depth. On rare occasions, dives could be deeper than seafloor depth because of the matching of whale location, diving depth, and seafloor depth at different spatial and temporal scales. A ratio of 1 was assigned when the beluga dive depth equaled or exceeded the ocean depth for a given location. We assumed ratios $>0.9$ represented benthic diving that targeted the seafloor. Close proximity to the seafloor, measured by dive to seafloor depth ratios, has previously been used to indicate benthic foraging for seals and the closely-related narwhal Monodon monoceros (Jessopp et al. 2013, Watt et al. 2015). We assumed ratios $<0.9$ corresponded to pelagic dives targeting other depths in the water column.

\section{Regional daily diving time budget model}

A daily diving time budget model was used to assess how individual belugas allocated time among depth layers within each region. We followed the approach developed for narwhals by Laidre et al. (2003) to estimate time spent both transiting through (i.e. transit time) and within (i.e. occupancy time) each depth layer. We tested differences in regional occupancy time at depth, after eliminating estimated time transiting to and from each depth, to assess population, sex, and age class differences. We presumed that extended occupancy time at deeper depths is related to foraging (Laidre et al. 2003). The model was based on scaling $6 \mathrm{~h}$ dive periods up to a $24 \mathrm{~h}$ period and used all 3 histogram types (i.e. maximumdepth, time-at-depth, and duration histograms). Since transmission of dive data were sometimes fragmented by poor satellite reception, analyses were restricted to $6 \mathrm{~h}$ periods when we had complete records of all 3 histogram types. Similar to above, we used a consolidated depth layer classification scheme that matched both maximum-depth and time-atdepth histogram types across all years (see Table S1): 0-10, 10-50, 50-100, 100-200, 200-400, and >400 m.

The time budget model required estimation of several parameters within each region for each tagged whale. Each parameter will be described briefly, using the same nomenclature as Laidre et al. (2003). First, region-specific vertical transit time $\left(\mathrm{TT}_{j}\right)$ was estimated as the average time spent transiting through each depth layer $(j)$ per day. Vertical transit time included time spent ascending and descending through each depth layer and relied on first estimating a population- and depth-specific vertical transit speed $\left(S_{j}\right)$ for each region (Heide-Jørgensen et al. 1998).

We estimated depth-specific vertical speeds for each population and region to account for potential behavioral differences among regions and between populations. Estimating a depth-specific vertical speed 
required a depth layer $(j)$ to be isolated such that dives were counted in the previous $(j-1)$ and next $(j+2)$ depth layers to estimate the speed through layer $j$. Sample size for vertical speed estimation was thus smaller than for the other daily time budget model parameters because there are fewer histograms that fit the constraint for isolated depth layers, particularly at each depth for all regions and both populations. This requirement limited the inclusion of regions for which a small number of samples were acquired, so we consolidated regions for vertical speed estimation for each population based on similar habitat types and used bootstrapping. The estimated population- and depth-specific vertical speeds for each habitat type were sampled with replacement 1000 times.

To estimate $\mathrm{TT}_{j}$ for each of the main regions, we applied the vertical speeds from the respective population and habitat type. Occupancy time $\left(\mathrm{OT}_{j}\right)$ within each depth layer was estimated by subtracting $\mathrm{TT}_{j}$ from the total time spent within each depth layer $j$ each day. Resulting $\mathrm{OT}_{j}$ values were the mean number of minutes a whale spent within each depth layer per day after removing transit time to and from that depth. To estimate occupancy time on a per dive basis (average occupancy time per dive, $\mathrm{AOT}_{\text {divej), }}$ ), $\mathrm{OT}_{j}$ was divided by the average number of dives per day to depth layer $j$.

For each region, we compared mean population responses of individual differences in $\mathrm{AOT}_{\text {divej }}$ using 2-way ANOVA. Factors included depth layers (i.e. 0$10,10-50,50-100,100-200,200-400$, and $>400 \mathrm{~m}$ ), population (BS and ECS) and their interaction. Limited sample size of BS whales precluded analysis of differences between sex or age classes, but we also tested differences in $\mathrm{AOT}_{\text {divej }}$ between ECS sexes and between ages (i.e. adult and immature ECS whales) in additional ANOVAs. We applied a squareroot transformation to each test of $\mathrm{AOT}_{\text {divej }}$ and evaluated model structure using Akaike's information criterion (AIC). Applying the Bonferroni correction for multiple comparisons, statistical significance of ANOVAs was considered at $\alpha=0.002$.

\section{Estimation of the vertical distribution of Arctic cod density in the western Beaufort Sea}

We estimated densities of age $1+$ Arctic cod within each beluga whale depth layer from $38 \mathrm{kHz}$ data collected during an acoustic-trawl survey in the western Beaufort Sea during 16 to 21 August 2008 (ParkerStetter et al. 2011; see trackline in Fig. 1). Age 1+
Arctic cod (hereafter simply 'cod') constituted >99\% of the Marinovich trawl (fishing dimensions 3-4 m vertical by $6 \mathrm{~m}$ horizontal) catches used to verify the species and size composition of fish within the midwater acoustic backscatter ( $\mathrm{n}=14$, Parker-Stetter et al. 2011), and cod was the dominant fish species across several recent surveys in the Beaufort Sea (Logerwell et al. 2015). The relatively small number of detections of age-0 Arctic cod (i.e. young of the year) or other species were not analyzed here and are not considered part of BS or ECS diets (Quakenbush et al. 2015). Integrated volume backscatter (area backscattering coefficient; $s_{a}$ in $\mathrm{m}^{2} \mathrm{~m}^{-2}$ ) of cod was exported in $10 \mathrm{~m}$ vertical depth bins, between $9.0 \mathrm{~m}$ below the surface and $0.5 \mathrm{~m}$ above the bottom, at a $500 \mathrm{~m}$ horizontal resolution. Density (no. fish $\mathrm{m}^{-2}$ ) was then calculated for each $10 \mathrm{~m}$ bin by dividing the integrated backscatter by a target strength of $-52.7 \mathrm{~dB}$ re $1 \mathrm{~m}^{2}$, estimated by Parker-Stetter et al. (2011). Cod densities in $10 \mathrm{~m}$ bins were then summed to vertical depth layers (i.e. 0-10, 10-50, 50-100, 100-200, 200-300, 300-400, >400 m) matching those used to identify the number of beluga dives made during $6 \mathrm{~h}$ periods (i.e. the $6 \mathrm{~h}$ maximum depth histograms). Cod densities along the survey trackline were next interpolated to create a smoothed surface of cod density for each beluga depth layer. We used ordinary kriging in the Geostatistical Analyst extension of ArcGIS 10.1, fitting a spherical model with no trend removal for each depth layer. Interpolation of cod density for each depth layer was limited to the bounds of the cod survey area other than the landward limit, which was set by the $100 \mathrm{~m}$ isobath used by Parker-Stetter et al. (2011) when estimating cod target strength. This landward limit was supported by beluga biology, since belugas detected by aerial surveys were most frequently located offshore of the $100 \mathrm{~m}$ isobath in the Alaska Beaufort Sea (e.g. Moore et al. 2000). We limited seaward interpolation of cod densities to the minimum depth threshold of each depth layer (e.g. the minimum isobath of the 200$300 \mathrm{~m}$ depth layer was $200 \mathrm{~m}$ ) when interpolating densities of cod in the deeper depth layers (i.e. 200$300,300-400$, and $>400 \mathrm{~m}$ ), and we refer to these as the $>200$, $>300$, and $>400 \mathrm{~m} \mathrm{cod}$ 'survey areas,' respectively.

\section{Statistical analysis of ECS beluga dive behavior relative to Arctic cod density}

We compared the pattern of beluga dive behavior to the depth-specific estimates of cod density within 
the cod survey area. A subset of 192 ECS beluga dive records that occurred within the survey area were used in this analysis. Few $(\mathrm{n}=4) \mathrm{BS} 6 \mathrm{~h}$ dive periods occurred in the cod survey area, which precluded similar comparisons. We were particularly interested in diving activity targeting the 100-200, 200-300, and 300-400 m depth layers, because we inferred that foraging likely occurred at these depths. Specifically, ECS belugas had prolonged occupancy time as well as maximum and modal dives to these depths in Barrow Canyon and the Alaska Beaufort Sea regions coinciding with the survey area (see 'Results'). These 'target' depths also match depths where fronts and upwelling occur in this area and promote the concentration of zooplankton, thereby presumably attracting beluga prey (Pickart et al. 2013, Stafford et al. 2013). Our goal was to examine whether the number of dives to these target depth layers corresponded with the depth layers at which cod were most abundant, indicating a relationship between inferred foraging dive depths and presumed prey patterns.

We used ECS beluga $6 \mathrm{~h}$ dive period locations that occurred within the cod survey area during July to October, when ECS belugas use Barrow Canyon and the Alaska Beaufort Sea (Hauser et al. 2014) and representing the period that is characteristic of when belugas dive to these target depth layers. We intersected the locations for each $6 \mathrm{~h}$ dive period within the $>200$ and $>300 \mathrm{~m}$ cod survey areas with each interpolated cod density depth layer. Generalized linear mixed models (GLMMs) were used to model the number of dives to specific target depth layers (i.e. 100-200, 200-300, and 300-400 m) using the 'Ime4' package in R (Bates et al. 2014). The number of dives to target depth layers was modeled using a Poisson error distribution and log link. Individual whales were considered a random effect to account for repeated measures and individual variation. We tested dive rates to $100-200$ and $200-300 \mathrm{~m}$ depth layers in the $>200 \mathrm{~m}$ survey area and also modeled dive rates to $200-300$ and $300-400 \mathrm{~m}$ in the $>300 \mathrm{~m}$ survey area. Explanatory variables for each GLMM included additive effects of cod densities in 10-50, 50-100, 100-200, and 200-300 m depth layers and log-transformed seafloor depth. We also included 2 additional predictor variables when modeling within the $>300 \mathrm{~m}$ survey area that were not appropriate for models in the $>200 \mathrm{~m}$ survey area: cod density in the 300-400 m depth layer, and a categorical variable identifying which depth layer contained the maximum cod density. Final model structure was determined via AIC model selection.

\section{RESULTS}

Four BS and 26 ECS beluga whales were tagged, resulting in 1600 and 7923 maximum depth $6 \mathrm{~h}$ histogram periods, respectively, within 10 Pacific Arctic regions (Tables 1 \& 2). For the BS whales, 1561 timeat-depth and 1610 duration $6 \mathrm{~h}$ histogram periods were also collected. We collected 8075 time-at-depth $6 \mathrm{~h}$ histogram periods and 7823 duration $6 \mathrm{~h}$ histogram periods for ECS whales. Belugas from both populations ranged across all but 1 of the Pacific Arctic regions (Table 1, Fig. 2). No dive data were collected in the Viscount Melville Sound BS summer core area, although it is typically used by BS males in July and August (Hauser et al. 2014). The majority of BS $6 \mathrm{~h}$ dive periods were obtained from the Chukchi Sea shelf $(34 \%)$, while the greatest percentage (31\%) of ECS $6 \mathrm{~h}$ dive periods were collected from the deep Canada Basin, Barrow Canyon slope (24\%), and Chukchi Sea shelf (21\%; Table 1). Seasonal presence varied among regions, and we are the first to document winter (November to April) and spring (May to June) behavior and locations of tagged belugas in the Bering Sea (Table 1, Fig. 2).

\section{Spatial patterns of dive behavior}

Geographically referenced dive data revealed differences in dive behavior among regions and between populations (Fig. 2). Maximum dive depth in $6 \mathrm{~h}$ periods was similar between populations for each region, ranging $>400 \mathrm{~m}$ in deep pelagic habitats (i.e. Canada Basin) where maximum dive depth never reached the seafloor. In slope areas, maximum dive depths were often $>400 \mathrm{~m}$ and typically (63 and $65 \%$ of $6 \mathrm{~h}$ periods for BS and ECS, respectively) reached the seafloor (Fig. 3). However, ECS belugas typically dove to mid-water depth layers (100-200 and 200-300 m) in the Barrow Canyon and Alaska Beaufort slope regions (Fig. 2). BS belugas also often dove to mid-water depths $(200-300 \mathrm{~m})$ in certain slope regions like Amundsen Gulf. Maximum dive depth in shelf areas was most frequently to $10-50 \mathrm{~m}(62 \%$ of $6 \mathrm{~h}$ periods) and to the seafloor ( $91 \%$ of $6 \mathrm{~h}$ periods) for ECS belugas. BS beluga shelf maximum dive depth was more frequently to $50-100 \mathrm{~m}(60 \%$ of $6 \mathrm{~h}$ periods) to typically reach the seafloor $(89 \%$ of $6 \mathrm{~h}$ periods).

Modal depths of $6 \mathrm{~h}$ periods were most frequently in the $<10$ and $10-50 \mathrm{~m}$ depth layers for both populations, regardless of habitat type (see Fig. S1). Dives $<10$ m represented surface-oriented dives (Citta et al. 

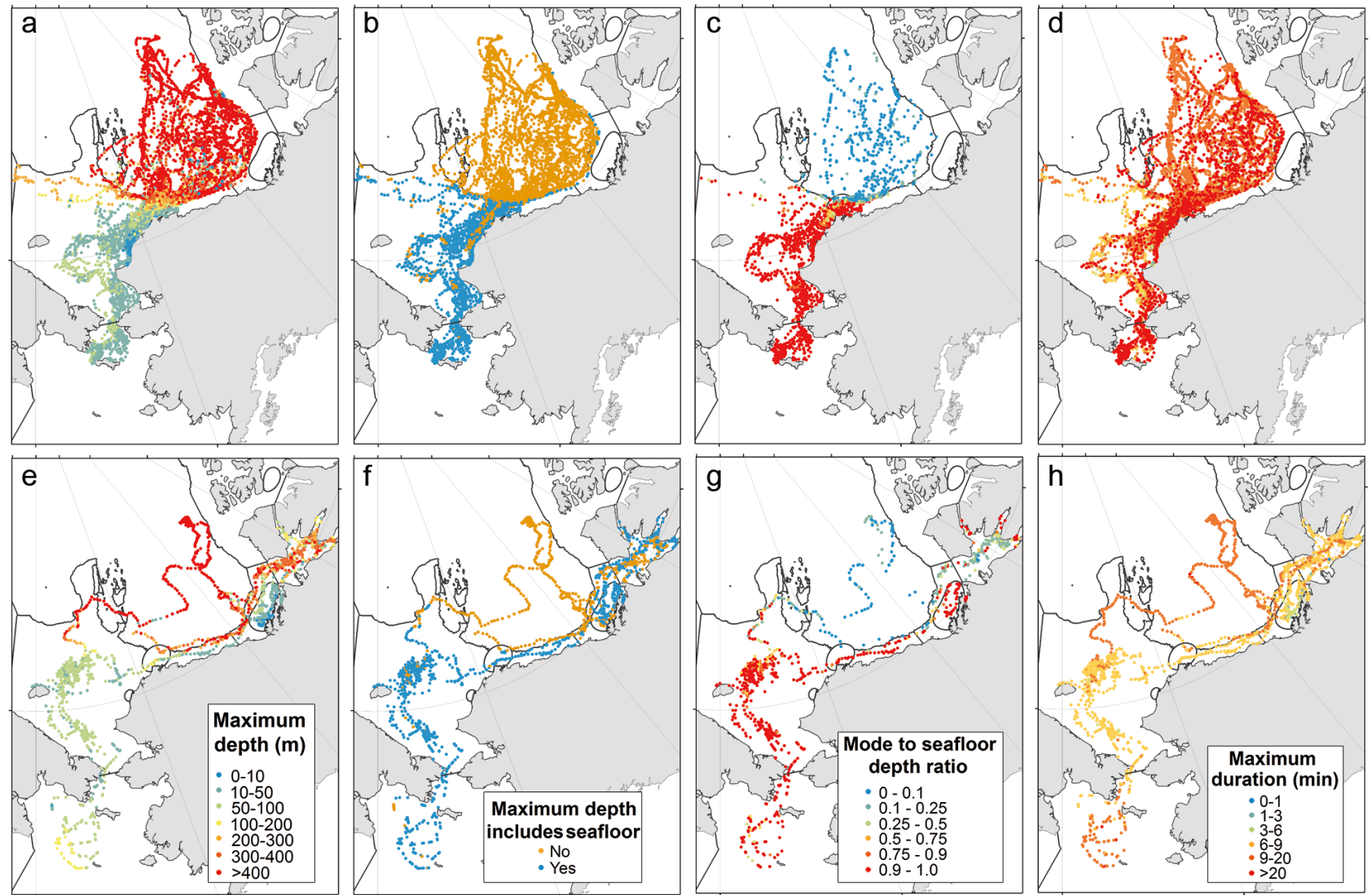

Fig. 2. Locations corresponding to each $6 \mathrm{~h}$ period for (a-d) Eastern Chukchi Sea and (e-h) Beaufort Sea beluga whales Delphinapterus leucas. Colors represent $(\mathrm{a}, \mathrm{e})$ maximum dive depth, $(\mathrm{b}, \mathrm{f})$ whether the maximum depth coincided with the seafloor, $(\mathrm{c}, \mathrm{g})$ the ratio of the most common (mode) diving depth to seafloor depth (excluding modal diving depths $<10 \mathrm{~m}$, and $(\mathrm{d}, \mathrm{h}) \mathrm{cat}-$ egories of maximum dive durations. Ratios $>0.9$ were considered benthic dives. Black lines delineate each region (see Fig. 1)

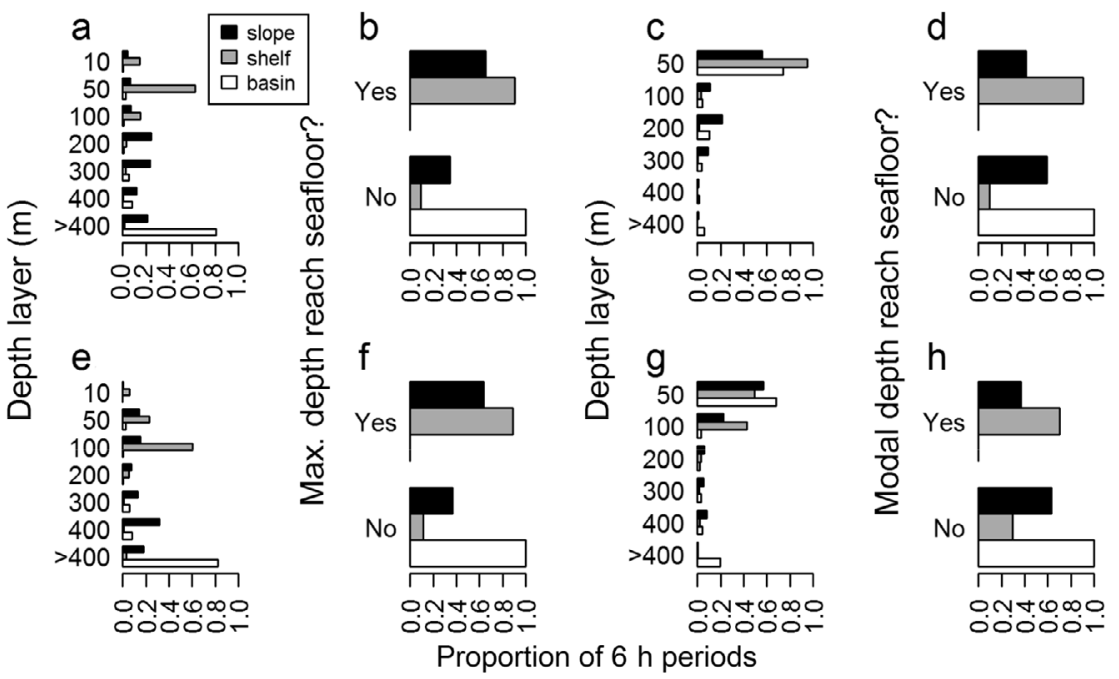

Fig. 3. Proportion of $6 \mathrm{~h}$ periods summarizing diving behavior to each depth layer by (a-d) Eastern Chukchi Sea (ECS) and (e-h) Beaufort Sea (BS) beluga whales Delphinapterus leucas in slope (black), shelf (grey), and deep pelagic 'basin' (white) habitat types (see Table 1 and Fig. 1). (a,e) Maximum dive depth; $(\mathrm{b}, \mathrm{f})$ whether maximum dive depth reached the seafloor; $(\mathrm{c}, \mathrm{g})$ modal dive depth; $(\mathrm{d}, \mathrm{h})$ and whether modal dive depth reached the seafloor
2013), so we excluded $6 \mathrm{~h}$ periods with $<10 \mathrm{~m}$ modal depths in subsequent modal dive depth analyses (resulting in $\mathrm{n}=962$ and $\mathrm{n}=2808 \mathrm{BS}$ and ECS $6 \mathrm{~h}$ periods, respectively). We most often observed modal dives in the 10-50 $\mathrm{m}$ depth layers for both populations in all habitat types (Fig. 3), but deeper dive depths were also common in some regions (Fig. 2). ECS modal depths in the 10-50 m depth layer (95\% of $6 \mathrm{~h}$ periods) were typically benthic dives $(90 \%$ of $6 \mathrm{~h}$ periods) within shallow shelf habitats (Fig. 3). BS modal depths in shelf habitats were common in the 10-50 and 50-100 m depth layers (50 and $43 \%$ of $6 \mathrm{~h}$ periods, respectively), and were less frequently benthic $(70 \%$ of $6 \mathrm{~h}$ periods) than those of ECS belu- 
gas in shelf habitats. BS modal dive to seafloor depth ratios were typically pelagic in the northern and northwestern Chukchi Sea (Fig. 2). In slope and deep pelagic habitats, modal depths for both populations were typically not benthic for BS $(63 \%$ and $100 \%$ of $6 \mathrm{~h}$ periods, respectively) or ECS belugas (59\% and $100 \%$ of $6 \mathrm{~h}$ periods, respectively), occurring most often in the 10-50 m depth layer but also in deeper depths (Fig. 3). Deeper modal depths were common in 100-200 and 200-300 m depth layers for ECS belugas in slope $(22 \%$ and $9 \%$ of $6 \mathrm{~h}$ periods, respectively) and basin (10\% and $4 \%$, respectively) habitats, especially in the Barrow Canyon and Alaska Beaufort Sea (Fig. 2). Additional modal depths for BS belugas were in the 50-100 and 300-400 m depth layers ( $23 \%$ and $8 \%$ of $6 \mathrm{~h}$ periods, respectively) in slope habitat, and $>400 \mathrm{~m}$ in deep pelagic habitat ( $20 \%$ of $6 \mathrm{~h}$ periods).

Maximum dive durations within a $6 \mathrm{~h}$ period were greater for ECS than BS whales (Fig. 2). Maximum dive duration was frequently $>20 \mathrm{~min}$ for ECS whales, while BS maximum dive durations were often 6-9 min throughout the Beaufort and Chukchi Seas and the Amundsen Gulf, compared to 9-20 min in the Canada Basin and the Bering Sea. Dive-depth and duration histograms were not directly linked within a $6 \mathrm{~h}$ period, so it was not possible to examine whether longer dives were also deeper dives.

Maximum daily depths recorded for 6 ECS tags deployed in 2007 to 2012 also varied regionally (LME, $\left.F_{6,16}=375.4, \mathrm{p}<0.0001\right)$ and never exceeded the $1000 \mathrm{~m}$ limit of their tags (Fig. 4). The deepest maximum daily depth recorded was $956 \mathrm{~m}$ for an adult male, although 2 adult females also attained maximum daily depths $>900 \mathrm{~m}$. The ratio of the maximum daily dive depth to ocean depth indicated that these whales were diving to the seafloor at least daily in all regions but the Canada Basin where seafloor depths ranged $>3000 \mathrm{~m}$. Within the Canada Basin, ECS belugas generally dove in excess of $600 \mathrm{~m}$ at least once daily $($ mean $=741.4 \mathrm{~m})$.

\section{Occupancy time at depth}

Depth-specific vertical speeds $\left(S_{j}\right)$ increased with depth for both populations in each habitat type (Fig. 5) and were similar in magnitude to those estimated for High Arctic belugas and narwhals (HeideJørgensen et al. 1998, Laidre et al. 2003). There were no significant differences in $\mathrm{AOT}_{\text {divej }}$ between populations within any region, but there were significant differences in $\mathrm{AOT}_{\text {divej }}$ among depth layers in all but the shallow shelf regions (i.e. the Bering and Chukchi Seas; Table 3, Fig. 6). Similarly, no significant differences between ECS male and female or immature and adult whales occurred in any region except the Canada Basin, where adult whales spent significantly more time at 200-400 and $>400 \mathrm{~m}$ depth layers than immature whales, presumably because adult whales have larger oxygen stores and aerobic capacity than smaller-bodied immature whales (Schreer \& Kovacs 1997, Noren \& Williams 2000). Occupancy times were greatest in the $200-400 \mathrm{~m}$ depth layer in the deep pelagic basin and some slope regions (Fig. 6). However, whales also spent more time in the 100-200 m depth layer in the Barrow Canyon and Alaska Beaufort slope regions.

\section{Vertical distribution of Arctic cod and beluga diving in the Alaska Beaufort Sea}

Age 1+ Arctic cod occurred throughout the water column during the fish survey, but the $200-300 \mathrm{~m}$ depth layer contained the highest cod densities of all depth layers regardless of water depth (see Fig. S2). This supports suggestions by Parker-Stetter et al. (2011) that cod aggregations extend into the Canada Basin in a horizontal pelagic layer as the seafloor drops steeply along the continental slope. Coincident with depth layers where cod were most dense, the greatest number of ECS beluga dives occurring within the cod survey area also targeted the 200$300 \mathrm{~m}$ depth layer other than dives closer to the surface in 10-50 m (Fig. 7). Maximum and modal dive depths also most frequently occurred in the 200$300 \mathrm{~m}$ depth layer, in addition to a mode near the surface at $10-50 \mathrm{~m}$.

The number of ECS beluga dives to 100-200, 200300 , and $300-400 \mathrm{~m}$ target depth layers was significantly related to the vertical distribution of cod density (Table 4). Cod density in 200-300 m was a consistently significant predictor for dive rates to each target depth, but cod density at other depths and seafloor depth were also related to dive rate for some models. Dive rate to a specific target depth was always negatively correlated with cod density at that same depth.

\section{DISCUSSION}

For marine mammals, targeted diving depths or extended occupancy at depth are often assumed to indicate foraging or the presence of predictable prey resources that may vary regionally or seasonally 

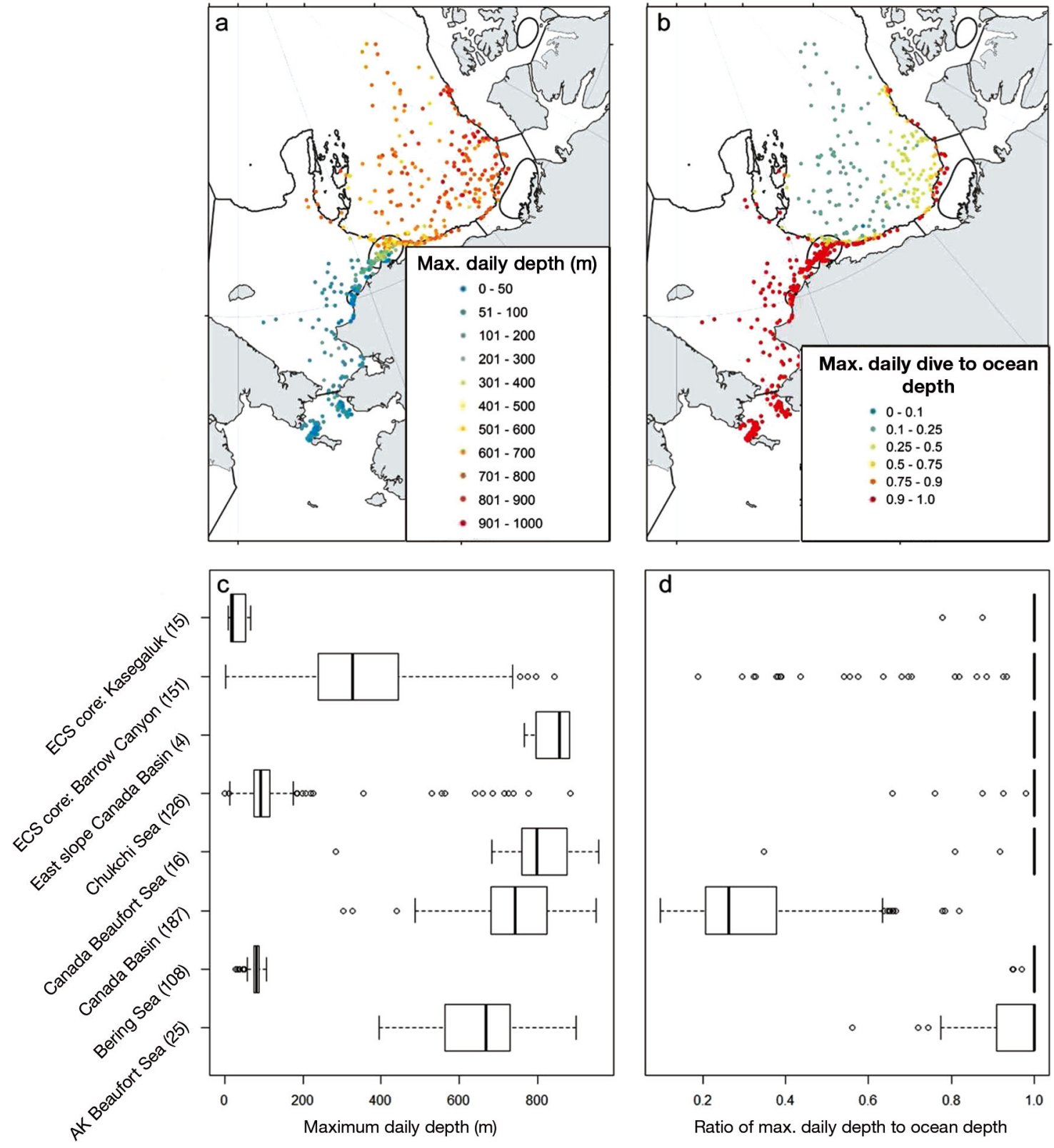

Fig. 4. (a) Maximum daily dive depth and (b) the ratio of maximum daily dive depth to ocean depth for 6 Eastern Chukchi Sea (ECS) beluga whales Delphinapterus leucas tagged in 2007, 2010, and 2012. Regions are outlined in black lines in panels (a) and (b) (see Fig. 1). Boxplots indicate regional (c) maximum daily dive depth and (d) ratios. Boxes represent the lower and upper quartiles, while black lines indicate median values. Extreme values and outliers are indicated by whiskers and open dots, respectively. The number of maximum daily dive depth records for each region is shown in parentheses on the $y$-axis. Ratios $>0.9$ were considered benthic dives in close proximity to the seafloor

(Laidre et al. 2003, Aguilar Soto et al. 2008, Robinson et al. 2012). In our study, spatial variation in diving behavior for BS and ECS beluga whales suggested different foraging strategies among regions and, in some cases, between populations. In the absence of high-resolution dive data, lower-resolution satelliterelayed data loggers, such as those used in our study, can still reliably estimate foraging behavior (e.g. Heerah et al. 2015). We determined foraging based on the maximum duration of dives, maximum (at $6 \mathrm{~h}$ and daily time scales) and modal dive depths, the proximity of dives to the seafloor, and the time spent within each depth layer. In studies where foraging can be confirmed, the deepest and longest maximum 

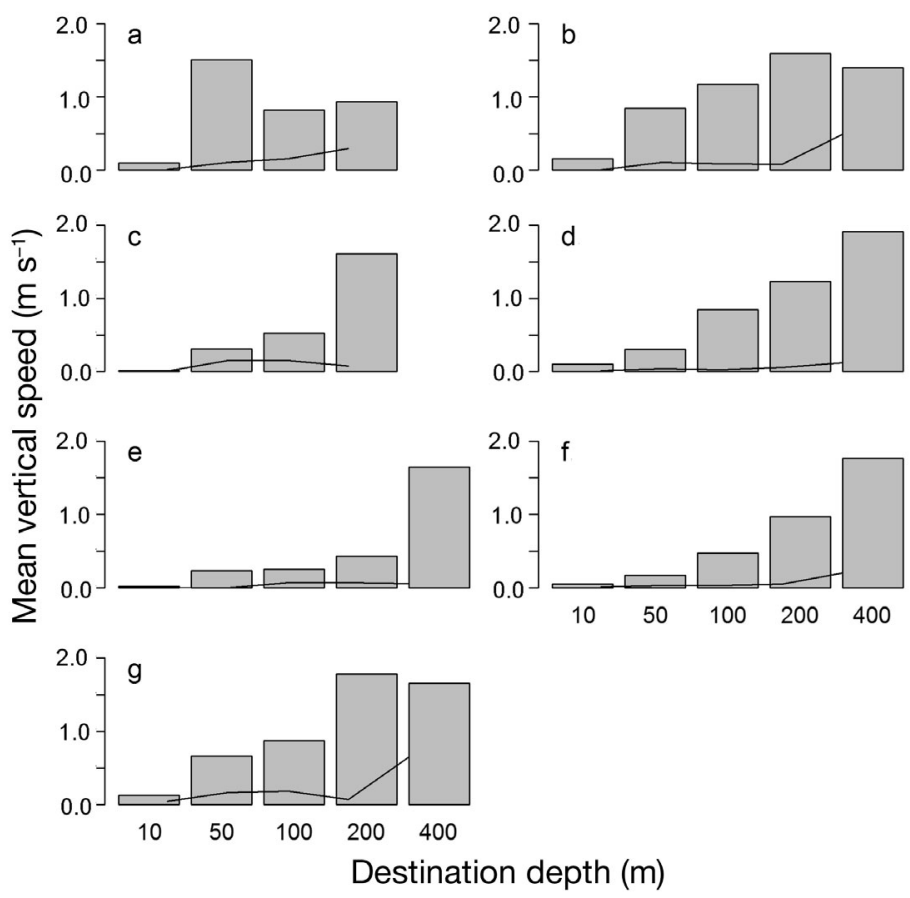

Fig. 5. Estimated mean vertical transit speed ( $S_{j ;}$ bars) among depth layers (shown as the maximum depth threshold) for $(\mathrm{a}, \mathrm{c}, \mathrm{e}, \mathrm{g})$ Beaufort Sea (BS) and $(\mathrm{b}, \mathrm{d}, \mathrm{f})$ Eastern Chukchi Sea (ECS) beluga whales Delphinapterus leucas in the Chukchi and Bering Seas $(\mathrm{a}, \mathrm{b})$ shallow shelf, $(\mathrm{c}, \mathrm{d})$ slope, $(\mathrm{e}, \mathrm{f})$ deep pelagic Canada Basin, and (g) Mackenzie Estuary and Amundsen shelf and slope habitat types. Lines indicate the standard deviation of vertical transit speed. No ECS belugas were found in the Mackenzie Estuary or Amundsen Gulf. No samples of $S_{j}$ were obtained for BS belugas in the 200-400 m depth layer in the Chukchi and Bering Seas (a) shallow shelf or (c) slope habitats, so the corresponding estimates from ECS whales were applied to the estimation of average occupancy time per dive $\left(\mathrm{AOT}_{\text {divej }}\right)$ in these cases

dive depths and durations are often associated with dives that have prey captures (e.g. Davis et al. 2013). The higher vertical speeds estimated here for deeper depths also support the assumption that foraging occurs at deeper depths. For example, high speeds at depth for some odontocetes coincide with foraging buzzes for particular prey types and the deepest parts of a dive (Aguilar Soto et al. 2008). Similarly, maximum dive depth serves as an indicator of foraging depth for benthic foragers (Photopoulou et al. 2014), and close proximity to the seafloor (or not) can be confirmed by comparing dive depth to water depth (Jessopp et al. 2013, Watt et al. 2015). Extended time at target depths has also been used to identify depth layers where foraging is expected to occur (Laidre et al. 2003). Our depth and duration histogram data could not be directly compared to indicate whether deeper dives were also longer

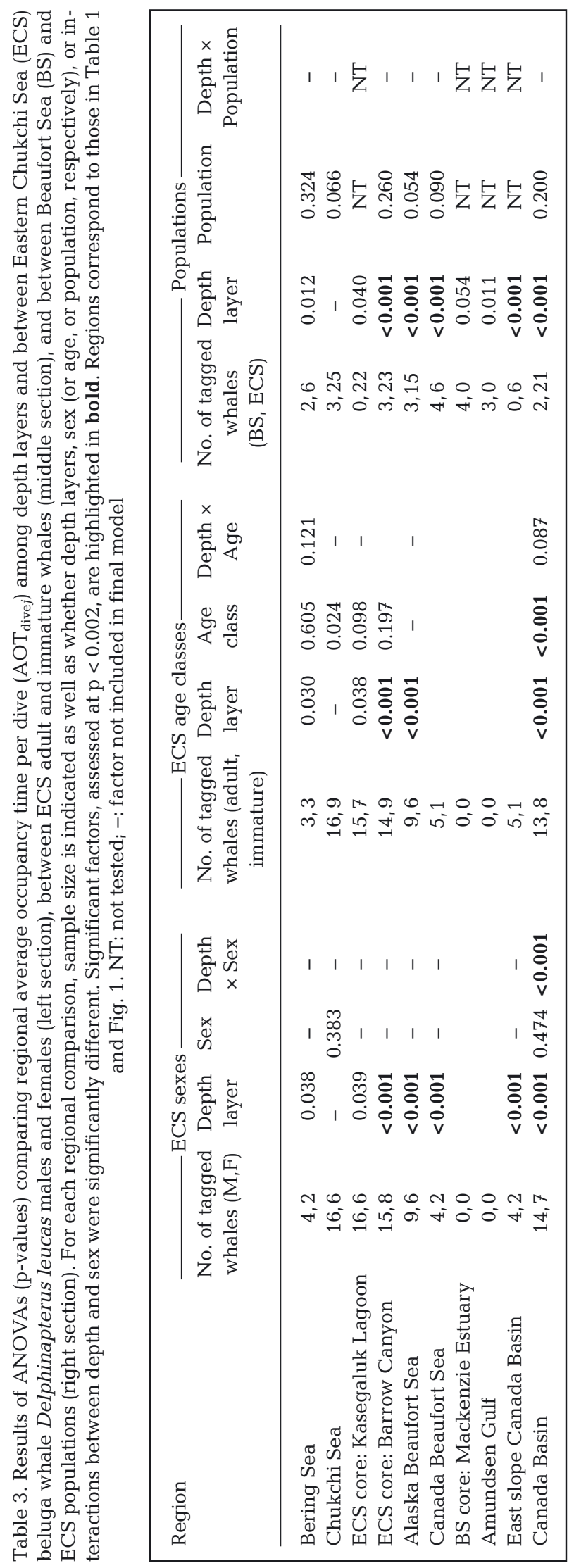



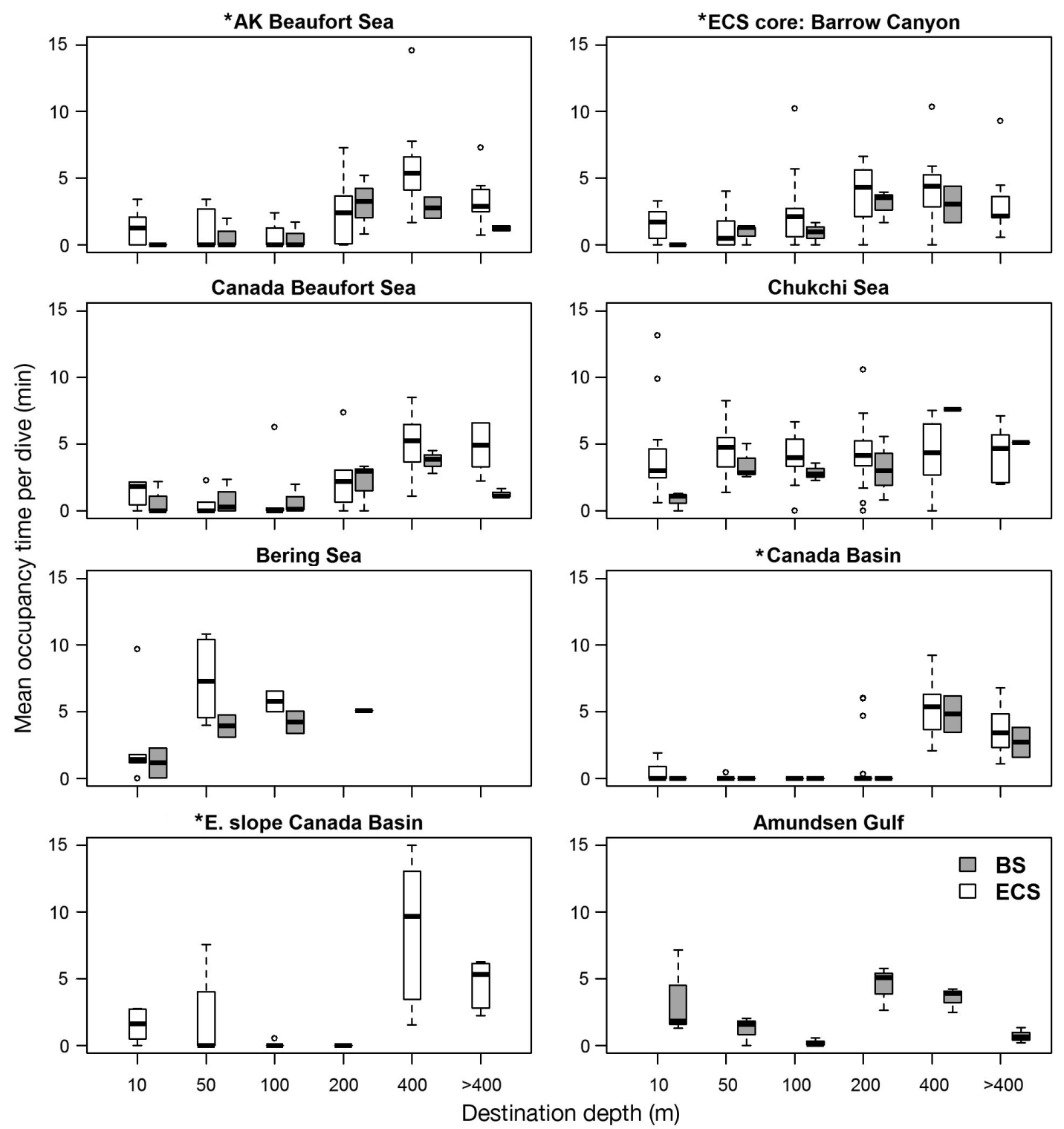

Fig. 6. Estimated average occupancy time per dive $\left(\mathrm{AOT}_{\text {divej }}\right)$ among depth layers (shown as the maximum depth threshold) in Pacific Arctic regions (see Fig. 1) for Beaufort Sea (BS) and Eastern Chukchi Sea (ECS) populations of beluga whales Delphinapterus leucas. Boxes represent the lower and upper quartiles, while black lines indicate median values. Extreme values and outliers are indicated by whiskers and open dots, respectively. Regions with significant differences $(\mathrm{p}<0.002)$ in $\mathrm{AOT}_{\mathrm{dive}}$ among depths are indicated by asterisks (see Table 3)

dives, but our estimates of depths with prolonged occupancy time corresponded well with maximum dive depths. Lastly, we estimated modal dive depths to identify the most common depths used by belugas.

\section{Non-foraging diving behavior}

Analysis of modal dive depths was complicated by the high frequency of shallow dives in the $0-10$ and 10-50 m depth layers (e.g. see Fig. S1). Citta et al. (2013) found that ECS belugas typically had a mode at the surface and another in a deeper layer. Bimodal distributions of maximum-depth histograms were still common after excluding dives $<10 \mathrm{~m}$, and the deeper of the 2 modes were used in analyses. We considered all depths in estimating modal dive depths, but we focused on modal dives $>10 \mathrm{~m}$ since we assumed dives in the upper $10 \mathrm{~m}$ were associated with surfacing behavior as in Citta et al. (2013). The 10-50 m depth layer was still often a primary mode, even when there may have been a second deeper mode. We assumed dives in the 10-50 m depth layer likely included surface-oriented behavior such as 

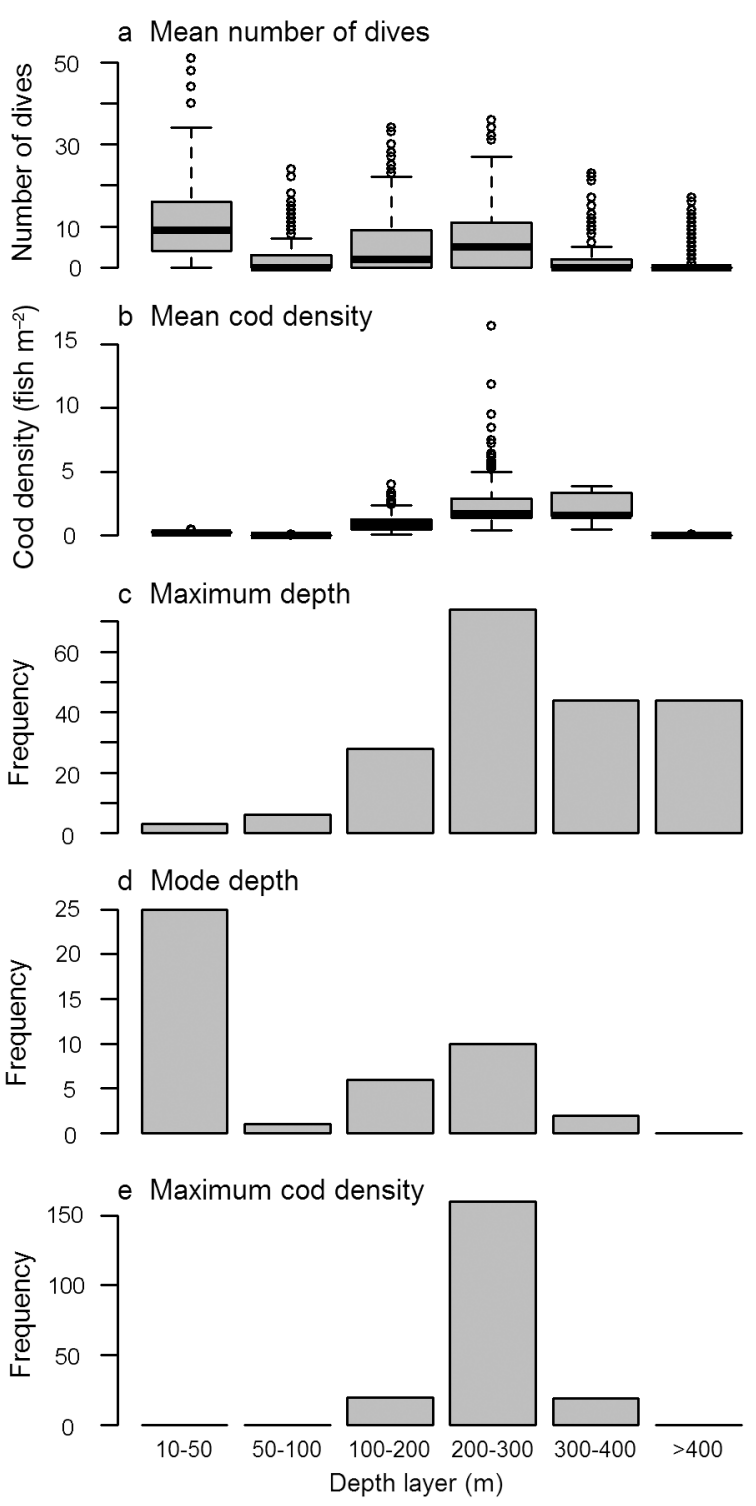

Fig. 7. (a) Mean number of Eastern Chukchi Sea (ECS) beluga whale Delphinapterus leucas dives, (b) mean Arctic cod Boreogadus saida density, (c) frequency distribution of ECS maximum dive depth, (d) frequency distribution of ECS modal dive depth, and (e) frequency distribution of which depth layer contained the maximum Arctic cod density among depth layers (or 'bins'), based on $6 \mathrm{~h}$ maximum depth periods within the Arctic cod $>200 \mathrm{~m}$ survey area $(\mathrm{n}=192$ periods). Arctic cod densities are based on intersecting beluga locations with interpolated surfaces of Arctic cod density (see Table S4 in the Supplement)

travel or recovery diving. Richard et al. (1997) provided evidence that shallower dives represent dive recovery or migration, reporting that BS belugas in areas 15-600 $\mathrm{m}$ deep and $>600 \mathrm{~m}$ would dive deeply followed by long periods with dives $<50 \mathrm{~m}$. Histograms and dive records from other deep-diving pred- ators also indicate concentrated and prolonged periods at shallow depths, consistent with travel and dive recovery following deep foraging dives (e.g. Laidre et al. 2003, Arranz et al. 2011). However, we cannot exclude the possibility that foraging occurred at $<50 \mathrm{~m}$, especially in shallow shelf habitats where water depths are often $\leq 50 \mathrm{~m}$, yet a deeper secondary mode is presumably associated with foraging in slope and deep pelagic habitats.

The coastal and shallow summer core areas of Kasegaluk Lagoon (mean depth $\sim 7 \mathrm{~m}$ ) and the Mackenzie River Estuary (mean depth $\sim 25 \mathrm{~m}$ ) are used by ECS and BS belugas, respectively, in spring to early summer during annual migrations (Hauser et al. 2014). Stomachs of belugas harvested during subsistence hunts near these regions are typically empty (Harwood \& Smith 2002, Quakenbush et al. 2015), although intestines were not examined. Histological studies of liver and kidney tissues from whales harvested in the areas also indicate fasting (Woshner et al. 2002). It seems unlikely that belugas forage in these coastal core areas and rather use them for an annual spring/summer molt where warmer and fresher water, such as near estuaries, accelerates epidermal regrowth (St. Aubin et al. 1990). Calving also occurs in spring, and shallow areas may provide thermal benefits to calves or provide additional protection from killer whale Orcinus orca predation (Finley 1982).

In contrast, the Canada Basin is a uniquely deep $(>3000 \mathrm{~m})$, pelagic, and historically ice-covered habitat where both populations had maximum dive depths $>400 \mathrm{~m}$ (see Figs. $2 \& 3$ ) and extended occupancy time at 200-400 and $>400 \mathrm{~m}$ (see Fig. 6). The average depth of maximum daily dives by ECS belugas $(741 \mathrm{~m})$ also suggested deep, pelagic diving (see Fig. 4). Richard et al. (1997) reported that male $\mathrm{BS}$ dives in the Canada Basin were typically ' $\mathrm{V}$ shaped' to $700-900 \mathrm{~m}$ for 15 to $20 \mathrm{~min}$ and accompanied by many dives $<50 \mathrm{~m}$, suggesting that these deep dives involved a whale reaching its maximum depth before immediately heading to the surface without searching for prey at depth. They hypothesized that whales may have used these dives to locate small breathing holes in the dense pack ice during ascent from depth and noted that V-shaped dives were not detected elsewhere. In addition to maximum dives $>400 \mathrm{~m}$ in Canada Basin, we found a secondary mode at $>400 \mathrm{~m}$ for BS belugas (see Fig. 3) that would support the description by Richard et al. (1997). ECS belugas may also have Vshaped dives based on their maximum dive depths, but ECS whales had additional modes at 100-200 
Table 4. Parameter estimates of the fixed effects of generalized linear mixed models for number of Eastern Chukchi Sea beluga whale Delphinapterus leucas dives to target depths. Analyses were restricted to $6 \mathrm{~h}$ maximum depth periods within either the $>200 \mathrm{~m}$ Arctic cod Boreogadus saida survey area ( $\mathrm{n}=192 \mathrm{six}$ h periods, from 20 whales) or $>300 \mathrm{~m}$ Arctic cod survey area ( $\mathrm{n}=68$ six h periods, from 16 whales) (see Fig. S3 in the Supplement, www.int-res.com/articles/suppl/m541p245_supp.pdf). The categorical explanatory variable 'depth layer with the maximum density of Arctic cod' (reference level $=100-200 \mathrm{~m}$ depth) was only included for models using the $>300 \mathrm{~m}$ survey area. Significant factors, assessed at $\mathrm{p}<0.05$, are highlighted in bold

\begin{tabular}{|c|c|c|c|c|}
\hline Response & Factor & Estimate & $\mathrm{SE}$ & $\mathrm{p}$ \\
\hline \multirow{4}{*}{ No. of beluga dives to $100-200 \mathrm{~m}$ (>200 m area) } & Intercept & 2.591 & 0.543 & $<0.001$ \\
\hline & Cod density $100-200 \mathrm{~m}$ & -0.095 & 0.043 & 0.029 \\
\hline & Cod density $200-300 \mathrm{~m}$ & 0.032 & 0.014 & 0.021 \\
\hline & $\log ($ depth $)$ & -0.189 & 0.088 & 0.032 \\
\hline \multirow[t]{3}{*}{ No. of beluga dives to $200-300 \mathrm{~m}$ (>200 m area) } & Intercept & 4.595 & 0.555 & $<0.001$ \\
\hline & $\log ($ depth $)$ & -0.484 & 0.094 & $<0.001$ \\
\hline & Cod density $200-300 \mathrm{~m}$ & -0.048 & 0.017 & 0.004 \\
\hline \multirow[t]{8}{*}{ No. of beluga dives to $200-300 \mathrm{~m}$ (>300 m area) } & Intercept & 1.120 & 0.440 & 0.006 \\
\hline & Cod density $50-100 \mathrm{~m}$ & -19.938 & 5.795 & $<0.001$ \\
\hline & Cod density $100-200 \mathrm{~m}$ & -0.245 & 0.141 & 0.084 \\
\hline & Cod density $200-300 \mathrm{~m}$ & -0.241 & 0.094 & 0.010 \\
\hline & Cod density 300-400 m & 0.441 & 0.169 & 0.009 \\
\hline & Depth of maximum cod density & & & \\
\hline & $200-300 \mathrm{~m}$ & 0.344 & 0.282 & 0.223 \\
\hline & $300-400 \mathrm{~m}$ & -0.420 & 0.316 & 0.183 \\
\hline \multirow[t]{9}{*}{ No. of beluga dives to $300-400 \mathrm{~m}$ (>300 m area) } & Intercept & 1.439 & 1.005 & 0.152 \\
\hline & Cod density $10-50 \mathrm{~m}$ & -5.341 & 2.124 & 0.012 \\
\hline & Cod density $50-100 \mathrm{~m}$ & -16.846 & 12.087 & 0.163 \\
\hline & Cod density $100-200 \mathrm{~m}$ & 1.114 & 0.221 & $<0.001$ \\
\hline & Cod density $200-300 \mathrm{~m}$ & 1.133 & 0.258 & $<0.001$ \\
\hline & Cod density 300-400 m & -1.191 & 0.431 & $<0.001$ \\
\hline & Depth of maximum cod density & & & \\
\hline & $200-300 \mathrm{~m}$ & -1.028 & 0.497 & 0.039 \\
\hline & $300-400 \mathrm{~m}$ & 0.574 & 0.508 & 0.259 \\
\hline
\end{tabular}

and 200-300 $\mathrm{m}$ in the Canada Basin (see Fig. 3) that may be associated with foraging. Relatively little is known about the distribution or abundance of potential prey in the Canada Basin, but boundary currents along the Chukchi and Beaufort shelves create mesoscale eddies that infuse nutrients and zooplankton into the region that could fuel higher trophic levels (Llinas et al. 2009). A stratified front is located $\sim 200-250 \mathrm{~m}$ between cold, dense Pacific water and warmer Atlantic water (Pickart 2004, Nikolopoulos et al. 2009) that could aggregate zooplankton, thereby attracting forage fish like Arctic cod (Logerwell et al. 2011). A dense layer of Arctic cod likely extends off the Beaufort Sea slope into the Canada Basin around $\sim 250 \mathrm{~m}$ depth (Fig. S2; Parker-Stetter et al. 2011). Another front is located between $\sim 600$ and $1000 \mathrm{~m}$ as the Atlantic water transitions to Deep Arctic water (McLaughlin et al. 1996). Ultimately, the functional importance of the Canada Basin remains somewhat unclear and may differ between BS and ECS belugas.

\section{Benthic diving behavior}

Our results indicated that both beluga populations primarily targeted either benthic or pelagic portions of the water column depending on the geographic region. Both maximum and modal dive depths suggested that both populations usually make benthic dives in shallow shelf habitats like the Chukchi and northern Bering Seas, but pelagic diving was more common in the deep Canada Basin (e.g. see Fig. 3). Stable isotope values from BS and ECS belugas suggest reliance on both benthic and pelagic prey (Dehn et al. 2006, Horstmann-Dehn et al. 2012), which fits the mixed pattern of benthic and pelagic diving among regions in our results. Benthic invertebrates (e.g. shrimp and echiurid worms) also dominated stomach contents of BS and ECS belugas sampled in spring and early summer when whales would have most recently been in the northern Bering or eastern Chukchi Seas (Quakenbush et al. 2015), further supporting a conclusion that benthic foraging occurs in 
these shallow shelf habitats. The northern Bering and Chukchi Seas are considered productive benthosdominated systems, with abundant and diverse benthic macrofauna (Grebmeier et al. 2006, Day et al. 2013) and benthic age 1+ Arctic cod (Norcross et al. 2013) that are potential beluga prey.

A small proportion of $6 \mathrm{~h}$ periods were characterized by non-benthic diving in the Chukchi and Bering Seas for BS belugas (see Fig. 2), which coincided with the deeper northern portions of the Chukchi Plateau and Herald Canyon. Although Herald Canyon is less affected by wind-driven fronts than Barrow Canyon in the eastern Chukchi Sea, easterly winds contribute to continental shelf waves over the western Chukchi Sea that can affect the transport of zooplankton and may have important effects on benthos as well as forage fish (Danielson et al. 2014). Relatively little is known about the distribution and abundance of potential beluga prey in the western Chukchi Sea. Similarly, circulation in the northwest Bering Sea fluctuates depending on wind stress, which is also a dynamic marginal sea ice zone in winter when BS belugas were present (Danielson et al. 2014). Few tags continued transmitting during winter in the Bering Sea, and additional work is needed to identify habitat use and foraging within this period.

In slope habitats, diving generally appeared to target the seafloor but also portions of the water column in certain regions. Maximum dive depths typically reached the seafloor (see Fig. 3) but varied depending on finer regions for the 2 populations (see Fig. 2). BS beluga diving focused on the seafloor in the Alaska Beaufort Sea and Barrow Canyon, while ECS belugas had more pelagic $6 \mathrm{~h}$ maximum and modal depths that corresponded to a frontal transition zone between Pacific and Atlantic water (Pickart 2004, Nikolopoulos et al. 2009) along the steep continental slope where age 1+ Arctic cod are most abundant (Parker-Stetter et al. 2011, Crawford et al. 2012). Both beluga populations made deeper dives in the Canada Beaufort slope region than in the Alaska Beaufort Sea, but rarely to the seafloor. Prolonged occupancy time at depth (see Fig. 6) as well as pelagic maximum and modal dive depths corresponded to the same depths of dense Arctic cod schools surveyed during summer and fall of 2006 to 2012 in the Canada Beaufort Sea and Amundsen Gulf (Geoffroy et al. 2015, Majewski et al. in press). However, Richard et al. (1997) reported 10 to $20 \mathrm{~min}$ 'square-shaped' dives to the seafloor by BS belugas in waters 15-600 m deep and assumed these were demersal foraging dives. These dives would typically be followed by several minutes at shallow depths or were conducted in batches trailed by multiple hours at $<50 \mathrm{~m}$. Nearly $37 \%$ of the modal dives we observed for BS belugas in slope waters reached the seafloor and may have represented similar square-shaped foraging dives. Our slightly different categorization of slope habitat as well as our sample of tagged whales may account for the apparent differences in our results. Of note, the sample of whales included in the study by Richard et al. (1997) was largely male and focused on use of the $600 \mathrm{~m}$ deep BS core area in Viscount Melville Sound compared to our largely female (and 1 immature male) sample that remained in Amundsen Gulf and the Canada Beaufort Sea before migrating west.

\section{Maximum dive duration}

ECS belugas almost universally had greater maximum dive durations than BS whales (see Fig. 2). The general similarities in diving behavior between populations is suggestive of comparable foraging patterns at depth within a given region, although spatiotemporal differences in BS and ECS movements (Hauser et al. 2014) would limit overlap and potential competition for prey at depth. Whales from the BS population are comparably sized to ECS whales (Suydam 2009), but our sample of tagged BS whales was biased toward females, with the only male being immature. Thus the difference in population-specific dive duration was likely due to the small sample of tagged BS whales. Additional tagging is needed to further compare dive durations between populations.

\section{Beluga dive patterns relative to the vertical distribution of cod}

Even with temporal mismatch between predator and prey sampling, significant relationships between predator diving and prey abundance can be detected (Kuhn et al. 2015). Despite asynchronous sampling between ECS beluga diving and cod density data, we assumed that observed patterns were representative of typical conditions. Several aspects of beluga behavior, diet, and regional hydrography support this assumption. Belugas are long-lived, social cetaceans with matrilineally derived migration routes and philopatry (O'Corry-Crowe 2008, Turgeon et al. 2012), suggesting that the same regions are used each summer by related social groups. ECS belugas exhibit strong interannual philopatry for areas in the 
Barrow Canyon and Alaska Beaufort Sea, areas which overlap with the fish survey area (Hauser et al. 2014). Beluga diving in the area targeted depths where fronts occur (e.g. occupancy time, maximum dive depth, dive rates to target depths, Citta et al. 2013). These persistent stratified fronts function to concentrate secondary production that likely attracts prey like Arctic cod and thus likely promote foraging opportunities for belugas in this area (Stafford et al. 2013). A simultaneously occurring benthic trawl survey supported the high biomass of cod found here and also indicated an association between Arctic cod and fronts (Logerwell et al. 2011). However, there have been few systematic surveys of cod in the Alaska Beaufort Sea for comparison to the distribution we observed (e.g. Lowry \& Frost 1981), and the area surveyed in this study likely did not fully sample the offshore extent of cod schools (Parker-Stetter et al. 2011). Yet age 1+ Arctic cod have dominated catches elsewhere in the eastern Chukchi and Beaufort Seas, especially on continental slopes that were consistently sampled in numerous years (e.g. Norcross et al. 2010, Crawford et al. 2012). Collectively, both pelagic and benthic surveys support our assumptions of cod density, suggesting a persistent pattern of high Arctic cod biomass in our survey area and throughout the Pacific Arctic (see also Logerwell et al. 2015).

In this study, depths of maximum and modal beluga dives were similar to depths with maximum and high mean cod densities (see Fig. 7). While recognizing that beluga dive behavior and cod distribution were not sampled concurrently, these results add weight to the use of our dive parameters as indicators of foraging behavior. The depth layer with the highest cod density (200-300 m) was a consistent, significant predictor of the number of ECS beluga dives (see Table 4) and suggested an overlap between beluga dive depths and high densities of Arctic cod, at least for ECS belugas in the survey area. Even though Arctic cod density consistently predicted the number of dives to target depths, we cannot exclude the possibility that other prey are pursued in this area. For example, belugas also dove to the seafloor and depth layers deeper than 200-300 m, although with much lower frequency.

We hypothesized that the number of beluga dives would increase with the density of cod, but we found a negative correlation between beluga dive rate to a target depth and cod density in that target or shallower depths. In contrast, there was a positive correlation with cod density at depths deeper than the target depth. This result suggests that belugas dive less frequently when cod are abundant because foraging is efficient at high prey densities, consistent with marginal value theorem predictions of optimal foraging (Charnov 1976). Empirical tests have demonstrated that other marine predators reduce foraging time in high-quality prey patches (e.g. Thums et al. 2013), and higher prey abundance improves foraging efficiency for deep divers (Goundie et al. 2015). For Pacific Arctic belugas, additional data are needed that incorporate simultaneous sampling of beluga behavior, cod distribution, and other potential prey to quantify the costs and benefits of beluga foraging on cod prey.

\section{CONCLUSIONS}

We used satellite-linked time-depth recorders to infer depths at which BS and ECS beluga whales forage throughout diverse regions of the Pacific Arctic. Maximum and modal dive depths suggested demersal foraging on shallow shelves like the Chukchi and northern Bering Seas in contrast to pelagic diving in the deep Canada Basin for both populations. While maximum dive depths often reached the seafloor in slope habitats, portions of the water column were more frequently targeted in certain regions. We also found that patterns of ECS beluga diving coincided with the depths at which Arctic cod were most abundant during a fisheries acoustic survey in the western Beaufort Sea, thereby providing additional support for our classification of foraging dives.

Our regional and population-specific estimates of foraging behavior provide important baseline information in the context of a rapidly transforming Arctic ecosystem that is increasingly exposed to anthropogenic activities (Grebmeier 2012). Industrial and other human activities (e.g. shipping and other vessels, mining, fishing, and tourism) are expanding and can potentially affect belugas directly (e.g. hearing impairment or stress response) or indirectly alter behavior (Reeves et al. 2014). Although both populations are considered stable stocks (Allen \& Angliss 2014), recent evidence for declining growth, body condition, and blubber thickness suggests that ecosystem changes may be affecting belugas through reduced availability or quality of prey (Harwood et al. 2014, 2015). Thus, understanding the behavioral use in each region offers a benchmark for which changes in beluga behavior can be assessed, as well as information to identify ecologically significant areas that may warrant protection. 
Acknowledgements. Tagging would not have been possible without the support of the Inuvialuit Hunter and Trapper Corporations of Inuvik, Aklavik, and Tuktoyaktuk, and Polar Continental Shelf Project for Beaufort Sea (BS) belugas or the village of Point Lay for Eastern Chukchi Sea (ECS) belugas. We are grateful to many people and organizations who were instrumental in tagging operations and data processing: J. Orr, A. Martin, B. LeBlanc (BS whales); L. Lowry, K. Frost, G. O'Corry-Crowe, D. Pikok, R. Small, J. Tazruk, J. Orr, A. Ashby, V. Dollarhide, L. Ferreira, R. Hobbs, R. Hoover, T. Nukapigak, L. Pierce, T. Romano, M. Sparck, H. Smith, S. Speckman, D. Susook, C. Aniskette, N. Hank, L. Hansen, L. Hoberecht, L. Quakenbush, T. Robeck, A. Simon, G. and K. VanBlaricom, B. and M. Tracey, J. Rexford, J. Taylor, J. Edwards, D. Ramey, and B. Achootchook (ECS whales). Funding for tagging was provided by the Alaska Beluga Whale Committee, Alaska Department of Fish and Game, Environmental Studies Revolving Fund, Fisheries and Oceans Canada (DFO), Fisheries Joint Management Committee, US Minerals Management Service (now US Bureau of Ocean Energy Management), National Marine Fisheries Service (NMFS), North Slope Borough of Alaska, North Slope Borough School District, and Village of Point Lay. Several people and organizations also supported the fish survey (see Parker-Stetter et al. 2011). We appreciate statistical advice from J. Ver Hoef. J. Nomura assisted with analysis of cod vertical distributions. Discussions with S. Moore and R. Hobbs helped develop this project, and J. Citta provided valuable feedback. Four anonymous reviewers contributed suggestions that greatly improved this manuscript. D.D.W.H. was supported by a fellowship from the University of Washington's Integrative Graduate Education and Research Traineeship Program on Ocean Change (National Science Foundation). All required permits for capture and tagging were approved by DFO for BS whales and by NMFS (nos. 14610, 782-1438, and 782-1719) for ECS whales.

\section{LITERATURE CITED}

Aguilar Soto N, Johnson MP, Madsen PT, Díaz F, Domínguez I, Brito A, Tyack P (2008) Cheetahs of the deep sea: deep foraging sprints in short-finned pilot whales off Tenerife (Canary Islands). J Anim Ecol 77:936-947

Allen BM, Angliss RP (2014) Alaska marine mammal stock assessments, 2013. Tech Memo NMFS-AFSC-277. US Department of Commerce, NOAA, NMFS, Seattle, WA

Amante C, Eakins BW (2009) ETOPO1 1 Arc-Minute Global Relief Model: procedures, data sources and analysis. Tech Memo NESDIS NGDC-24. National Geophysical Data Center, NOAA, Boulder, CO

> Arranz P, Aguilar Soto N, Madsen PT, Brito A, Bordes F, Johnson MP (2011) Following a foraging fish-finder: diel habitat use of Blainville's beaked whales revealed by echolocation. PLoS ONE 6:e28353

Bates D, Maechler M, Bolker BM, Walker S (2014) lme4: linear mixed-effects models using Eigen and S4. R package version 1.1-7. Available at http://CRAN.R-project.org/ package $=\operatorname{lme} 4$

> Boyd IL (1997) The behavioral and physiological ecology of diving. Trends Ecol Evol 12:213-217

> Carmack EC, Macdonald RW (2002) Oceanography of the Canadian shelf of the Beaufort Sea: a setting for marine life. Arctic 55:29-45
Carmack EC, Wassman P (2006) Food webs and physicalbiological coupling on pan-Arctic shelves: unifying concepts and comprehensive perspectives. Prog Oceanogr 71:446-477

- Charnov EL (1976) Optimal foraging, the marginal value theorem. Theor Popul Biol 9:129-136

> Citta JJ, Suydam R, Quakenbush L, Frost KJ, O'CorryCrowe G (2013) Dive behavior of Eastern Chukchi beluga whales (Delphinapterus leucas), 1998-2008. Arctic 66:389-406

Crawford R, Vagle S, Carmack E (2012) Water mass and bathymetric characteristics of polar cod habitat along the continental shelf and slope of the Beaufort and Chukchi seas. Polar Biol 35:179-190

> Danielson SL, Weingartner TJ, Hedstrom KS, Aagaard K, Woodgate R, Curchitser E, Stabeno PJ (2014) Coupled wind-forced controls of the Bering-Chukchi shelf circulation and the Bering Strait throughflow: Ekman transport, continental shelf waves, and variations of the PacificArctic sea surface height gradient. Prog Oceanogr 125: 40-61

> Davis RW (2014) A review of the multi-level adaptations for maximizing dive duration in marine mammals: from biochemistry to behavior. J Comp Physiol B 184:23-53

> Davis RW, Fuiman LA, Madden KM, Williams TM (2013) Classification and behavior of free-ranging Weddell seal dives based on three-dimensional movements and video-recorded observations. Deep-Sea Res II 88-89: 65-77

> Day RH, Weingartner TJ, Hopcroft RR, Aerts LAM and others (2013) The offshore northeastern Chukchi Sea, Alaska: a complex high-latitude ecosystem. Cont Shelf Res 67:147-165

- Dehn LA, Follmann EH, Rosa C, Duffy LK and others (2006) Stable isotope and trace element status of subsistencehunted bowhead and beluga whales in Alaska and gray whales in Chukotka. Mar Pollut Bull 52:301-319

Finley KJ (1982) The estuarine habitat of the beluga or white whale, Delphinapterus leucas. Cetus 4:4-5

> Freitas C, Lydersen C, Fedak MA, Kovacs KM (2008) A simple new algorithm to filter marine mammal Argos locations. Mar Mamm Sci 24:315-325

Frost KJ, Lowry LF (1990) Distribution, abundance, and movements of beluga whales, Delphinapterus leucas, in coastal waters of western Alaska. Can Bull Fish Aquat Sci 224:39-57

Geoffroy M, Majewski AR, LeBlanc M, Gauthier S, Walkusz W, Reist JD, Fortier L (2015) Vertical segregation of age0 and age-1+ polar cod (Boreogadus saida) over the annual cycle in the Canadian Beaufort Sea. Polar Biol (in press), doi:10.1007/s00300-015-1811-z

> Goundie ET, Rosen DAS, Trites AW (2015) Low prey abundance leads to less efficient foraging behavior in Steller sea lions. J Exp Mar Biol Ecol 470:70-77

> Grebmeier JM (2012) Shifting patterns of life in the Pacific Arctic and Sub-Arctic seas. Annu Rev Mar Sci 4:63-78

Grebmeier JM, Cooper LW, Feder HM, Sirenko BI (2006) Ecosystem dynamics of the Pacific-influenced northern Bering and Chukchi Seas in the Amerasian Arctic. Prog Oceanogr 71:331-361

Harwood LA, Smith TG (2002) Whales of the Inuvialuit Settlement Region in Canada's western Arctic: an overview and outlook. Arctic 55:77-93

Harwood LA, Kingsley MCS, Smith TG (2014) An emerging pattern of declining growth rates in belugas of the Beau- 
fort Sea: 1989-2008. Arctic 67:483-492

> Harwood LA, Smith TG, George JC, Sandstrom SJ, Walkusz W, Divoky GJ (2015) Change in the Beaufort Sea ecosystem: diverging trends in body condition and/or production in five marine vertebrate species. Prog Oceanogr 136:263-273

> Hauser DW, Laidre K, Suydam R, Richard P (2014) Population-specific home ranges and migration timing of Pacific Arctic beluga whales (Delphinapterus leucas). Polar Biol 37:1171-1183

Heerah K, Hindell M, Guinet C, Charrassin J (2015) From high-resolution to low-resolution dive datasets: a new index to quantify the foraging effort of marine predators. Anim Biotelemetry 3:42

> Heide-Jørgensen MP, Richard P, Rosing-Asvid A (1998) Dive patterns of belugas (Delphinapterus leucas) in waters near eastern Devon Island. Arctic 51:17-26

> Horstmann-Dehn L, Follmann EH, Rosa C, Zelensky G, George JC (2012) Stable carbon and nitrogen isotope ratios in muscle and epidermis of arctic whales. Mar Mamm Sci 28:E173-E190

Jakobsson M, Mayer LA, Coakley B, Dowdeswell JA and others (2012) The International Bathymetric Chart of the Arctic Ocean (IBCAO) Version 3.0. Geophys Res Lett 39: L122609

> Jessopp M, Cronin M, Hart T (2013) Habitat-mediated dive behavior in free-ranging grey seals. PLoS ONE 8:e63720

> Johnson DS, London JM, Lea MA, Durban JW (2008) Continuous-time correlated random walk model for animal telemetry data. Ecology 89:1208-1215

> Kuhn CE, Sterling JT, Zeppelin TK (2015) Linking northern fur seal behavior with prey distributions: the impact of temporal mismatch between predator studies and prey surveys. Anim Biotelemetry 3:9

> Laidre KL, Heide-Jørgensen MP, Dietz R, Hobbs RC, Jørgensen OA (2003) Deep-diving by narwhals Monodon monoceros: differences in foraging behavior between wintering areas? Mar Ecol Prog Ser 261:269-281

Laidre KL, Stirling I, Lowry LF, Wiig O, Heide-Jorgensen MP, Ferguson SH (2008) Quantifying the sensitivity of arctic marine mammals to climate-induced habitat change. Ecol Appl 18:S97-S125

> Llinas L, Pickart RS, Mathis JT, Smith SL (2009) Zooplankton inside an Arctic Ocean cold-core eddy: probable origin and fate. Deep-Sea Res II 56:1290-1304

> Logerwell EA, Rand K, Weingartner TJ (2011) Oceanographic characteristics of the habitat of benthic fish and invertebrates in the Beaufort Sea. Polar Biol 34:1783-1796

Logerwell EA, Busby M, Carothers C, Cotton S and others (2015) Fish communities across a spectrum of habitats in the western Beaufort Sea and Chukchi Sea. Prog Oceanogr 136:115-132

> Loseto LL, Stern GA, Connelly TL, Deibel D and others (2009) Summer diet of beluga whales inferred by fatty acid analysis of the eastern Beaufort Sea food web. J Exp Mar Biol Ecol 374:12-18

Lowry LF, Frost KJ (1981) Distribution, growth, and foods of Arctic cod (Boreogadus saida) in the Bering, Chukchi, and Beaufort seas. Can Field Nat 95:186-191

Majewski AR, Walkusz W, Lynn BR, Atchison A, Eert J, Reist JD (2015) Distribution and diet of demersal Arctic cod, Boreogadus saida, in relation to prey availability and habitat characteristics in the Canadian Beaufort Sea. Polar Biol (in press), doi:10.1007/s00300-015-1857-y

- McLaughlin FA, Carmack EC, Macdonald RW (1996) Physi- cal and geochemical properties across the Atlantic/ Pacific water mass front in the southern Canada Basin. J Geophys Res 101:1183-1197

Moore SE, DeMaster DP, Dayton PK (2000) Cetacean habitat selection in the Alaskan Arctic during summer and autumn. Arctic 53:432-447

Nikolopoulos A, Pickart RS, Fratantoni PS, Shimada K, Torres DJ, Jones EP (2009) The western Arctic boundary current at $152^{\circ} \mathrm{W}$ : structure, variability, and transport. Deep-Sea Res II 56:1164-1181

Norcross BL, Holladay BA, Busby MS, Mier KL (2010) Demersal and larval fish assemblages in the Chukchi Sea. Deep-Sea Res II 57:57-70

> Norcross BL, Raborn SW, Holladay BA, Gallaway BJ and others (2013) Northeastern Chukchi Sea demersal fishes and associated environmental characteristics, 20092010. Cont Shelf Res 67:77-95

Noren SR, Williams TM (2000) Body size and skeletal muscle myoglobin of cetaceans: adaptation for maximizing dive duration. Comp Biochem Physiol A Mol Integr Physiol 126:181-191

O'Corry-Crowe G (2008) Climate change and the molecular ecology of Arctic marine mammals. Ecol Appl 18:S56-S76

O'Corry-Crowe GM, Suydam RS, Rosenberg A, Frost KJ, Dizon AE (1997) Phylogeography, population structure and dispersal patterns of beluga whale Delphinapterus leucas in the western Nearctic revealed by mitochondrial DNA. Mol Ecol 6:955-970

Orr JR, Joe R, Evic D (2001) Capturing and handling of white whales (Delphinapterus leucas) in the Canadian Arctic for instrumentation and release. Arctic 54:299-304

Palacios DM, Baumgartner MF, Laidre KL, Gregr EJ (2013) Beyond correlation: integrating environmentally and behaviourally mediated processes in models of marine mammal distributions. Endang Species Res 22:191-203

Parker-Stetter SL, Horne JK, Weingartner TJ (2011) Distribution of polar cod and age-0 fish in the U.S. Beaufort Sea. Polar Biol 34:1543-1557

Photopoulou T, Fedak MA, Thomas L, Matthiopoulos J (2014) Spatial variation in maximum dive depth in gray seals in relation to foraging. Mar Mamm Sci 30:923-938

Pickart RS (2004) Shelfbreak circulation in the Alaskan Beaufort Sea: mean structure and variability. J Geophys Res 109:C04024

> Pickart RS, Schulze LM, Moore GWK, Charette MA, Arrigo KR, van Dijken G, Danielson SL (2013) Long-term trends of upwelling and impacts on primary productivity in the Alaskan Beaufort Sea. Deep-Sea Res I 79:106-121

Pinheiro J, Bates D, DebRoy S, Sarkar D, R Development Core Team (2013) nlme: linear and nonlinear mixed effects models. R package version 31-107, https://cran.rproject.org/web/packages/nlme/index.html

Quakenbush L, Suydam R, Bryan AL, Lowry LF, Frost KJ, Mahoney BA (2015) Diet of beluga whales (Delphinapterus leucas) in Alaska from stomach contents, MarchNovember. Mar Fish Rev 77:70-84

R Development Core Team (2012) R: a language and environment for statistical computing. R Foundation for Statistical Computing, Vienna

Reeves RR, Ewins PJ, Agbayani S, Heide-Jørgensen MP and others (2014) Distribution of endemic cetaceans in relation to hydrocarbon development and commercial shipping in a warming Arctic. Mar Policy 44:375-389

Richard PR, Martin AR, Orr JR (1997) Study of summer and fall movements and dive behavior of Beaufort Sea belu- 
gas, using satellite telemetry: 1992-1995. Environmental Studies Research Funds No. 134. ESRF, Calgary

Richard PR, Orr JR, Martin AR (2001) Summer and autumn movements of belugas of the Eastern Beaufort Sea stock. Arctic 54:223-236

Robinson PW, Costa DP, Crocker DE, Gallo-Reynoso JP and others (2012) Foraging behavior and success of a mesopelagic predator in the northeast Pacific Ocean: insights from a data-rich species, the northern elephant seal. PLoS ONE 7:e36728

Schoener TW (1971) Theory of feeding strategies. Annu Rev Ecol Syst 2:369-404

Schreer JF, Kovacs KM (1997) Allometry of diving capacity in air-breathing vertebrates. Can J Zool 75:339-358

Seaman GE, Lowry LF, Frost KJ (1982) Foods of Belukha whales (Delphinapterus leucas) in western Alaska. Cetology 44:1-19

Spall MA, Pickart RS, Fratantoni PS, Plueddemann AJ (2008) Western Arctic shelfbreak eddies: formation and transport. J Phys Oceanogr 38:1644-1668

St. Aubin DJ, Smith TG, Geraci JR (1990) Seasonal epidermal molt in beluga whales, Delphinapterus leucas. Can J Zool 68:359-367

Stafford KM, Okkonen SR, Clarke JT (2013) Correlation of a strong Alaska Coastal Current with the presence of beluga whales Delphinapterus leucas near Barrow, Alaska. Mar Ecol Prog Ser 474:287-297

Suydam R (2009) Age, growth, reproduction, and movements of beluga whales (Delphinapterus leucas) from the eastern Chukchi Sea. PhD dissertation, University of Washington, Seattle, WA

Suydam RS, Lowry LF, Frost KJ, O'Corry-Crowe GM, Pikok DJ (2001) Satellite tracking of eastern Chukchi Sea bel-

Editorial responsibility: Rory Wilson, Swansea, UK uga whales into the Arctic Ocean. Arctic 54:237-243

> Thompson D, Fedak MA (2001) How long should a dive last? A simple model of foraging decisions by breath-hold divers in a patchy environment. Anim Behav 61:287-296

Thums M, Bradshaw CJA, Sumner MD, Horsburgh JM, Hindell MA (2013) Depletion of deep marine food patches forces divers to give up early. J Anim Ecol 82:72-83

Turgeon J, Duchesne P, Colbeck GJ, Postma LD, Hammill MO (2012) Spatiotemporal segregation among summer stocks of beluga (Delphinapterus leucas) despite nuclear gene flow: implication for the endangered belugas in eastern Hudson Bay (Canada). Conserv Genet 13:419-433

von Appen WJ, Pickart RS (2012) Two configurations of the western Arctic shelfbreak current in summer. J Phys Oceanogr 42:329-351

Watt CA, Orr JR, Heide-Jørgensen MP, Nielsen NH, Ferguson SH (2015) Differences in dive behaviour among the world's three narwhal Monodon monoceros populations correspond with dietary differences. Mar Ecol Prog Ser 525:273-285

Weingartner TJ, Cavalieri DJ, Aagaard K, Sasaki Y (1998) Circulation, dense water formation, and outflow on the northeast Chukchi shelf. J Geophys Res 103:7647-7661

Witteveen BH, De Robertis A, Guo L, Wynne KM (2015) Using dive behavior and active acoustics to assess prey use and partitioning by fin and humpback whales near Kodiak Island, Alaska. Mar Mamm Sci 31:255-278

> Woshner VM, O'Hara TM, Eurell JA, Wallig MA, Bratton GR, Suydam RS, Beasley VR (2002) Distribution of inorganic mercury in liver and kidney of beluga and bowhead whales through autometallographic development of light microscopic tissue sections. Toxicol Pathol 30: 209-215

Submitted: March 9, 2015; Accepted: October 23, 2015 Proofs received from author(s): December 3, 2015 